\title{
The Similar-Sounding Surnames of Haplogroup R-BY140757
}

\author{
by Dr Mike Fitzpatrick ${ }^{1, *} \underline{\underline{\square}}$ and lan Fitzpatrick ${ }^{2} \underline{\underline{\square}}$ \\ ${ }^{1}$ Independent Scholar, Auckland 0604, New Zealand \\ ${ }^{2}$ Genealogist, Newmarket L3Y 7C9, Canada \\ *Author to whom correspondence should be addressed
}

Journal of the Fitzpatrick Clan Society 2021, 2, 1-41

\begin{abstract}
Y-DNA analysis is a remarkable method that can inform patrilineal genealogies, both ancient, and modern. Applied here to facilitate a critical review of Branan pedigrees, an analysis of haplogroup R-BY140757 results in a deep questioning of the dominant narratives of the O'Braonáin Uí Dhuach (O'Brenan of Idough). What results is a disruption of those narratives that is total.
\end{abstract}

The O'Braonáin Uí Dhuach, held by Ossorian historians to share descent from Cearbhall, King of Osraí (843-888 AD), we argue, are not Osraighe, but are an Uí Failghi tribe - this based on the ultimate authority of Dubhaltach Mac Fhirbhisigh. Hence, Y-DNA connections between Branans, or those with similar-sounding surnames, and related others, are a false trail for those who claim descent from Cearbhall.

Once Mac Fhirbhisigh is embraced, and the erroneous pedigrees of the O'Braonáin Uí Dhuach are set aside, the origins of men with Branan, and similar-sounding surnames, of haplogroup R-BY140757, can be correctly determined. And, based on Y-DNA haplotype analysis, it is considered those origins are not with the O'Braonáin Uí Dhuach, or any Irish clan.

Rather, haplotype R-BY140757 appears to have originated from a family who settled near Braham, in Suffolk, after the Norman conquest of England. The key figure in the appearance of R-BY140757 pedigrees in Éire is Sir Robert de Braham, who was Sheriff of Kilkenny ca. 1250 AD.

\section{A Note on Names, Styles, Edits, Records, and DNA}

This article is written in the English language, but the people and places discussed are Irish. In order to acknowledge the primacy of Gaeilge (Gaelic) in this article, the personal names and by-names of people, and place names, are provided in modern Gaeilge using the most common spelling; for example Áth na nUrlainn (Urlingford), unless the place name is titular, for example, the Lord of Kilkenny.

Quotations are italicised, and long or textually significant quotations are also indented. This article is a living work, i.e., it can be edited by the authors; all versions will be retained.

Every effort has been made to consult all available records that relate to the period relevant 
to this article, and Y-DNA data is current to the date of publication. Y-DNA dating estimates are probabilistic should be considered \pm two generations, i.e., \pm approximately sixty years.

Mac Lysaght (1985) determined the surname Brennan stemmed from Ó Braonáin, being the 'name of four unrelated septs', one of which was located in Osraí. Mac Lysaght pains to add that the Gaelic name Ó Braonáin was also anglicised as Brannan - a point not to be overlooked. In this article the reader will see reference to other similar-sounding surnames; in this article we use Branan as the generic form.

\section{Introduction}

On a first reading of the seminal works on the Ó Braonáin Uí Dhuach, it is easy to be swept up and carried away on a warm summer current, perhaps even by the old An Fheoir (River Nore) herself. To be sure, she has seen Ó Braonáin greatness pass over countless generations, and her flow, or so it seems, could tell of their exploits for countless more generations to come.

Graves (1850) declared the 'country of the Ó Braonáin' was Uí Dhuach (Idough) in Osraí and was, therefore, ultimately under the 'supreme rule of the great Mac Giolla Phádraig', who 'parcelled out amongst subordinate clans' the various 'ancient tribe-districts' in their kingdom. The poor relations in this supposed land-deal were close kindred of their imperious overlords, since the respective clan progenitors were said to share a direct paternal ancestor - Braonáin was a son of Cearbhall, King of Osraí (843-888 AD), and Giolla Pátraic was one of Cearbhall's great-grandsons, via Braonáin's brother Cellach, King of Osraí (905-908 AD).

This article will demonstrate easily enough that the idea Mac Giolla Phádraig ever exercised supreme rule over all Osraí is fraught (Brennan, 1979), and this is particularly relevant to Uí Dhuach. Less easy to demonstrate is that the Ó Braonáin' were, in O'Hart's (1892) words, 'Princes of Idough'. To date, there has been only one published exposition of the Ó Braonáin Uí Dhuach that goes beyond the general, once-over, type of approach. The definitive 'History of the Brennans of Idough, County Kilkenny' by Thomas A Brennan (1975) is a fine work - well-sourced and fully referenced, the tome reflects the author's depth of thought and is a lasting resource for anyone with interest in the history not only of Ó Braonáin Uí Dhuach, but also of Osraí.

While Brennan's book is enduring, the advent of Y-DNA surname projects has led to no small mystery concerning some with the surname Branan, who trace their origins to Osraí. That YDNA findings can be highly disruptive of personal family narratives (Scholar, 2020) is unsurprising. That Y-DNA findings on a broader family scale may result in the disruption of entire clan narratives (Fitzpatrick \& Fitzpatrick, 2020a) should, on reflection, also come as no great surprise. The dominant want to remain dominant, even if that means burying some historical records and fabricating new ones. And there are clear examples of 'deliberate censorship and falsification' of genealogical records by medieval Irish historians on behalf of those seeking to 'find historical justification' for a royal lineage, and such titles as Taoiseach (chieftain), or Rí (king) (Simms, 2004). 
Such corruption of pedigrees cuts close to the bone for Mac Giolla Phádraig Osraí, whose lineages were 'obviously manipulated in favour of the later dominant dynastic group', that group being the descendants of Giolla Phádraig mac Donnchada (Lord of Osraí, 1039-1055 AD) (Ó Corráin, 1977). And the genealogical sins of omission and commission in historical accounts of Mac Giolla Phádraig and Fitzpatricks have been a recurring theme ever since the compilation of regnal lists in the Book of Leinster (O'Brien, 1976); more recently they are found in the works of Shearman (1879), Carrigan (1905), and Zalewski and Fitzpatrick (2002) (Fitzpatrick, 2020a; Fitzpatrick 2020b).

In this regard, a cynic might point to Shearman being on the payroll of John Wilson Fitzpatrick (Royal Society of Antiquaries of Ireland, 1879), the first Lord Castletown, who, perhaps with the Victorian chip of illegitimacy weighing heavy on his mind, determined the need to include himself in Shearman's Ossorian genealogy, 'proving', at least to himself, his descent from Crimthann Coscrach, a second-century king of Éire. Shearman ignored a plethora of key records at his disposal, such as those found in the Patent Rolls of Ireland (e.g., Irish Record Commission, 1800), and in doing so effectively disposed of lineages that may have threatened Lord Castletown's claims regarding the primacy of his descent.

Reverend Carrigan, excellent in many respects, was possibly also subject to conflicts of interest; he was a sidestepper of unbecoming acts by clergy (Comerford, 2005) and avoided an exposition of the clerical lineages of Mac Giolla Phádraig Osraí, which must have been known to him (Fitzpatrick, 2020a; Fitzpatrick 2020b) - granted, the suite of Papal records available to Carrigan was not as complete as it is today.

However, the work of Zalewski and Fitzpatrick is an abject failure and a modern-day example of how dominant narratives can be perpetuated by those blindly motivated by vanities, such as the identification of 'The Fitzpatrick, chief of his name' (Zalewski \& Fitzpatrick, 2002) - as if there could ever be just one person, and that necessarily a man, to represent a surname with such diverse origins (Fitzpatrick \& Fitzpatrick, 2020a). To ignore records in both the Patent Rolls and the Papal Registers, in a day and age when those records are so readily accessible, is no small feat of dereliction and incompetence.

The intrusion of a conversation about doubts surrounding Mac Giolla Phádraig lineages, into an article on the Ó Braonáin Uí Duach, is significant to the purpose of the paper. The doubts stem from a Y-DNA connection between men called Branan within haplogroup R-

A1506>AY140757, and Fitzpatricks within a sibling haplotype, R-A1506>A1496 - it's a genetic connection that might be seen as obvious evidence for shared ancestry out of Cearbhall. However, that idea is disrupted with the understanding R-A1506 may have Norman origins, challenging not only narratives of the Barons of Upper Ossory's descent from Cearbhall (Fitzpatrick \& Fitzpatrick, 2020a) but those of related lines as well. But what if the Branan genetic 'cousins' of the Fitzpatricks of Ossory possess a different descent and a different narrative than being Ó Braonáin Uí Dhuach, of an Osraighe line - a much more complex and unexpected descent? And perhaps even more radically - what if Ó Braonáin ancestors of Cearbhall, king of Osraí, do not even exist today?

Such questions are central to this article, the purpose of which is to critically review the Ó Braonáin Uí Dhuach using a twenty-first-century approach - that of using all readily 
available historical records in conjunction with a Y-DNA analysis of men in Haplogroup R140757 who have surnames that are similar-sounding to Branan.

An array of relevant historical records have come within much closer reach, enabled via modern accessibility, than was ever enjoyed by the likes of Shearman and Carrigan. And, the analysis of Y-chromosome single nucleotide polymorphisms (SNPs) has evolved to the extent that patrilineal connections never before imaginable have become so obviously apparent that a disruption of the traditional narratives is unavoidable.

\section{Article Overview}

This article involves a journey across realms and epochs, beginning with an understanding of the túath (clan-people-nation-district) of Uí Dhuach within the overkingdom of Osraí, then progressing to review the genealogical and annalistic accounts Uí Dhuach chieftains, king Cearbhall of Osraí, and the Ó Braonáin Uí Dhuach, as far as those accounts are relevant to this article's conversation. The direction of the article changes once considerations are given where and when haplogroup R-BY140757 arose, which leads to Cill Chainnigh (Kilkenny), then to the Colony of Virginia, on to Yorkshire, and then to Suffolk, and then back again to Cill Chainnigh. The article signposts are:

- The divisions of Osraí and Uí Dhuach.

- The chieftains of Uí Dhuach.

- Cearbhall and the kingship of Osraí.

- The Ó Braonáin Uí Dhuach.

- R-BY140757 descendants of early Virginia colonists.

- The de Braham of Yorkshire.

- The de Braham of Suffolk.

- Haplogroup R-A1506.

- The de Braham of Cill Chainnigh.

- Explaining the R-BY140757 haplotree.

- Conclusions: conclusive and otherwise.

\section{The divisions of Osraí and Uí Dhuach}

No minor difficulty comes when attempting to synthesise and determine the names and geopolitical boundaries of the various divisions of Osraí across several hundred years. Even at the top of the regional political hierarchy of Éire, where things might be considered the least complex, the earliest recorded designation that the Island comprised a discreet provincial 'cuig cuigidh', or 'five fifths', (Uladh, Chonnacht, Teamhair, Dinn Riogh, and Mumhan, i.e., Ulster, Connaught, Tara (i.e., north Leinster), south Leinster, and Munster; MacNeill, 1920) is an oversimplification (Koch \& Holley, 2006). Futile, then, are attempts to neatly package provincial sub-kingdoms and, under those, túath through the ages and across the dynasties.

The earliest accounts place Osraí within Dinn Riogh, the southern fifth of Laighean (Leinster), which O'Donovan identified as centred near Leithghlinn an Droichid 
(Leighlinbridge) (O'Clery, 1856). There is no dissent that the border of eastern Osraí was along An Bhearú (River Barrow), and stretched from the modern-day Barony of Gabhrán (Gowran) in Cill Chainnigh westward across to Gréin: 'Osraige ö Gabran co Gréin' (MacNeill, 1920). At a western extremity, MacNeill (1920) identified Gréin as An tSeanphailís (Pallas Grean) in eastern Luimneach (Limerick). Much more likely, and based on sounder reason, is that Gréin refers to Grian Airbh in Cill Chainnigh, near Áth na nUrlainn (Urlingford) and the Tiobraid Árann (Tipperary) border (Morris, 1922). O'Heerin's early fifteenth-century topographical poem (O'Dubhagain, O'Donovan, \& O'Huidhrin, 1862) leaves little doubt regarding the latitudinal boundaries of Osraí, succinctly described as from 'Bladhma out to the sea', i.e., from Sliabh Bladhma (Slieve Bloom) to Muir Cheilteach (the Celtic Sea).

As detailed by Carrigan (1905), numerous sub-kingdoms and túath of Osraí can be identified, but it is the location Uí Dhuach that holds the attention for this article. The modern-day parish of Bábhún Ó nDhuach (Odagh) in the Barony of Fásach an Deighnín (Fassadinin), northern Cill Chainnigh, still bears witness to a territory once much more extensive. At the commencement of the shiring of Ireland by the Anglo-Normans in the thirteenth century, the subsequent sub-division of Irish counties into cantreds occurred as greater settlement proceeded (Otway-Ruthven, 1980). The cantreds of medieval Cill Chainnigh numbered eleven, but they were not closely similar to the county baronies extant today. The cantred known as Idough enveloped the modern-day baronies of Fásach an Deighnín and Gabhalmhaigh (Galmoy), and parts of the baronies of Crannach (Crannagh), Clann Donncha (Clandonagh), and Clár Maí Locha (Clarmallagh) (Empey, 1971).

Hogan (1864) argued the ancient túath of Uí Dhuach was identical to Airgeadros (or Airgead Rós) - the Silver Wood, and this because of their contextual use, side by side, in a reference to 'Cathal, son of Dubhan, lord of Ui-Dhuach-Argad-rois' who died in 850 AD (O'Clery, 1856). And Hogan maintains Ui-Dhuach was derived from 'Fearadhach, son of Dhuach, Lord of Osraighe' who was slain in 582 AD (O'Clery, 1856). Although Hogan was unable to make any connection between Fearadhach and Airgead Rós, according to Ó Murchada (1999) the first use of Uí, meaning descendants, occurs in 579 AD with reference to the Uí Fhailge whose ancestor was Failge Berraide (d. 516 AD). Hence, any use of Uí Dhuach after 582 AD would be consistent with the timeframe for the introduction of Uí in the formulation of Irish surnames and its contemporaneous use in referencing the túath of Uí Dhuach.

Carrigan's case for the etymology of Uí Dhuach is effectively the same as Hogan's, i.e., it comes from a line of fifth-century Mumhan (Munster) kings who ruled Osraí, stemming from one called Concraid, son Dhuach Cliach (Carrigan, 1905). The genealogies of Mac Fhirbhisigh enable the determination that Dhuach Cliach was the father of Fearadhach, and a link between Dhuach Cliach and Airgeadros can be made with certainty because Mac Fhirbhisigh names Carn Mugana of Airgeadros as Dhuach Cliach's great-grandson (Mac Fhirbhisigh \& Ó Muraíle, 2003).

Having come to an understanding of when, where, and why the túath of Uí Dhuach emerged, there is a need to critique what historians, such as Hogan and Carrigan, relate concerning the entrance of the Ó Braonáin into Uí Dhuach. 


\section{The chieftains of Uí Dhuach}

Graves (1850) states, 'brief and scanty are the notices of the chieftains of Ui Dhuach afforded by the Annals of the Four Masters', and correctly so. One could also add the notices have resulted in confusion, and have been misinterpreted and exaggerated; important here is a sound understanding of just who, exactly, were the chieftains of Ui-Dhuach. Further accuracy is found with Hogan (1864), who notes, 'it does not appear that the O'Breannains at any time held possession of the entire territory of Ui-Dhuach'. Who, then, were the other possessors, and when was their reign?

The record of Cathal, son of Dubhan, lord of Uí Dhuach, (O'Clery, 1856), is the first mention of the túath in the Annals; unfortunately, neither Cathal nor Dubhan have been identified (Brennan, 1979). More than a century lapses before Uí Dhuach is heard of again, this time when, in 951 AD, 'Faelan son of Tadhg, Tanist of Ui Ceinnsealaigh; and Duibhginn, son of Cuileannan, lord of Ui-Dhuach, died on the same day' (O'Clery, 1856). Once again, there is difficulty identifying the lord of Uí Dhuach, but there is, at least, a clue that the Uí Dhuach were at war with the Ui Ceinnsealaigh at this time. That war may have been part of a wider conflict between Osrai and the Laigin, which rumbled on throughout the tenth century (O'Clery, 1856; MacCarthy, 1895).

That being the case, it is not unreasonable to suggest the Uí Dhuach may have been allied with Osraí tribes. Still, such conjecture does not fit with the record of events of 1026 AD, that is, if those events retrospectively reveal who the lords of Uí Dhuach probably were in $951 \mathrm{AD}$ :

Aimergin Ua Mordha, lord of Laeighis, and Cuduiligh Ua Beargdha, lord of Uí Dhuach, were mutually slain by each other; and the Ui-Dhuach and Laeighisi were mutually slaughtered, but the Uí Dhuach were defeated (O'Clery, 1856).

The variable interpretations of this key entry in the Annals of the Four Masters range from the ridiculous to the sublime. The passage is completely misrepresented by both Graves (1850), who called it a 'bloody contest between the O'Broenains, and their neighbours, the O'Mores of Leix', and Murphy (1879), who counted the battle was between the Ua Mordha and the Ua Beargdha was somehow 'won by the O'Brenans'; the reasons why Graves, and Murphy, confound the Ua Beargdha with O'Braonáin are difficult to understand.

Shearman (1878) equated the Ua Beargdha with Uí Bairrche, and said there were four Laighean tribes who bore the name, the most 'historic' being the descendants of Daire Barrach, the son of Cathair Mór. Shearman also stated it was not they, but another Ua Beargdha tribe who were lords of Uí Dhuach ca. 1026 AD, they being the descendants of those displaced by Concraid, son Dhuach Cliach, although Shearman fails to identify the Ua Beargdha line of descent. Shearman's assertion is self-contradicted when he says O'Brenans supplanted the rulers of Uí Dhuach in the tenth century. The only concept that affords an escape from the confusion of Shearman's complex narrative is that there were multiple rulers of Uí Dhuach. 
A more natural and straightforward identification of Ua Beargdha Uí Dhuach is they descend from Beargdha of Clann Chairbre; Cairbre being a son of king Flann dá Chongal, of the Uí Failghi. Indeed these Ua Beargdha do not descend from Daire Barrach, but his brother, Ros Failge (Mac Fhirbhisigh \& Ó Muraíle, 2003). The proximity of Uí Failghi clans to Uí Dhuach ca. 1026 AD was to the north, and also not distant - and at that time the Uí Failghi were at war with the Ó Mórdha. Given that Mac Fhirbhisigh records it was an Ó Beargdha clan who were lords of Uí-Dhuach, and one of the 'three principal chieftains of Osrai' (Mac Fhirbhisigh \& Ó Muraíle, 2003), at the time of Concraid, mac Dhuach Cliach's conquest, it is not the least implausible that in 1026 AD the same clan was simply partaking in a struggle for Uí Dhuach that had occupied them for several centuries.

Such details might appear peripheral to the overall thread of this article, but, as will be seen, there are connections to be made with Ó Beargdha that relate to the Mac Fhirbhisigh genealogy of the O'Braonáin Uí Dhuach. However, at this juncture, it is enough to state, O'Braonáin were not lords of all Ui-Dhuach in 1026 AD, although they were becoming something of note (Brennan, 1979); sufficiently so that, around that time, Donnchadh Mac Giolla Phádraig, the Lord of Osraí, had married 'the daughter of the chief O'Brenan of Idough' (Lodge, 1789).

What, then, can be revealed that is any different to the narratives of the likes of Groves and Shearman, who have the O'Braonáin Uí Dhuach as the descendants of Cearbhall, King of Osraí? First, it is necessary to understand just who those descendants were.

\section{Cearbhall and the kingship of Osraí}

Cearbhall is the name given to three kings of Osraí in Lebhor Laignech (the Book of Leinster). Cearbhall II and Cearbhall III ruled portions of Osraí in the twelfth century (O'Sullivan, 1983). Cearbhall I, the son of Dúnghal, was king of Osraí (842-888 AD), and was referred to by Carrigan as perhaps 'the most famous of the kings of Ossory'; that fame is doubtless partly due to his fortune in having his exploits recorded in the Fragmentary Annals (Donovan, 1860).

Cuilen, the eldest son of Cearbhall, was slain by Norsemen in 886 AD. A dirge for Cuilen, recorded by the Annalists, reads, 'we did not think that Cuilen would, thus, have perished, we thought he would be king' (O'Clery, 1856). On Cearball's death, the kingdom of Osrai came to his brother, Riacán; and it was during his term, in 890 AD, that another of Cearbhall's sons, Braonáin, was killed 'by the Deisi' (O'Clery, 1856). Riacán, who was advanced in years, died in $894 \mathrm{AD}$, after suffering at the hands of Diarmait, another son of Cearbhall, who became the next king (Best \& MacNeill, 1933; O'Donovan, 1860).

Diarmait's reign was marked by infamy and fracture - the determination that Osaraí came to be broken up, 'into three small separate states, each with its own line of rulers or kings' following the death of Giolla Pátraic Rúad in 1103 AD (Carrigan, 1905), can be traced back to events involving Diarmait approximately two centuries earlier. Although all factors are not recorded, Diarmait's cruelty toward Riacán is likely to have formed a basis for the descendants of Dúnghal deposing him in 900 AD, driving him out of Osraí, and installing his brother Ceallach, the fourth son of Cearbhall, in his place (O'Clery, 1856). And yet, Diarmait 
would make a return. Stripped of his kingdom, he found solace with Cearbhall mac Muirecáain, the king of Leinster. These events resulted in Ceallach having a natural sway toward Mumhan, following in the footsteps of his father, Cearbhall. Cearbhall had taken 'honourably' to Horm of the Danes, who were the enemies of Laighean and the Norwegians, therefore they shared the common enemies of Mumhan (O'Donovan, 1860).

In $908 \mathrm{AD}$, at the instigation of Flathbertach the Abbot of Inis Cathaigh, Cormac the bishopking of Caiseal (Cashel) and ruler of Cúige Mumhan (Kelly, 1895), assembled his armies and marched on Laighean to demand payment under the pretext that it was owing under the terms of Leath Mogha (Keating, 1723), that is, the requirement for kingdoms in the southern half of Ireland to pay tribute to the king of Caiseal. The king of Leinster sought peace, offering jewels to Flathbertach and Cormac ( $\mathrm{O}^{\prime}$ Donovan, 1860), and hostages in the form of one of his own sons as well as Diarmait, the deposed king of Osrai - the latter pair to be held in safekeeping by Maenach, the Abbot of Díseart Diarmada (Castledermot) (Keating, 1723; O’Donovan , 1860).

When Flathbertach refused the offer, the stage was set for one of the most bloody battles ever fought on Irish soil, that of Bealach Mughna in Cill Dara (Ballaghmoon, Co. Kildare) (Healy, 1893), where six thousand men purportedly fell (Donovan, 1860). Flathbertach failed to take into account that the king of Leinster would draw on the support of Flann Sinna, king of Éire (879-916 AD), who had an Osraí interest - Flann Sinna's mother was Flann, daughter of Dúnghal (O'Clery, 1856), the sister of Cearbhall, i.e., the dethroned Diarmait's uncle was the king of Éire.

In the slaughter that followed, there fell many nobles, including Ceallach, king of Osraí, and his son, and Cormac, the king of Cúige Mumhan - Flathbertach avoided death, but he was captured. At the end of the battle, Flann Sinna 'came with a numerous royal body of horse, and he escorted Diarmait, son of Cearbhall, into the kingdom of Osraige'; having ratified a peace between Diarmait and his kin, Flann Sinna reinstated him as king of Osraí (O’Donovan, 1860).

Despite being provided with a second chance, Diarmait's infamy did not cease, and peace in Osraí was short-lived. Just four years later, in 912 AD, Diarmait saw fit to slay his nephew, the son of Braonáin. Many of Diarmait's kin, referred to in the Fragmentary Annals as Clann Dúnghal, rose against him; notable was his first cousin Mael Mordha, the son of Riacán, who remembered the,

'cruelty that Diarmait had shown towards his father when he was an old man'. So it was that 'many nobles were killed ... and many churches were wasted ... and Osraige was divided in two by that war' (O'Donovan, 1860).

The division of Osraí doubtless resulted in a clamour for Uí Dhuach since it was one of Osraí's largest regions, and desirable also for its 'warm soil' (O'Dubhagain, O'Donovan \& O'Huidhrin, 1862) and 'fertile and sheltered limestone-gravel districts' (Graves, 1850) - Uí Dhuach was not a region to be given, or taken, on a whim. When and how, then, was it wrested from the Ó Beargdha to come into the possession of Ó Braonáin descendants of Cearbhall, king of Osraí? The short answer is - it didn't.

(C) Copyright 2021 | All rights reserved | The Fitzpatrick Clan Society

Fitzpatrick, M., Fitzpatrick, I. (2021). The Similar-Sounding Surnames of Haplogroup R-BY140757. The Journal of the Fitzpatrick Clan Society 2, 1-41. doi:10.48151/fitzpatrickclansociety00421, 25 June 2021 


\section{The Ó Braonáin Uí Dhuach}

The Reverend John Francis Shearman was upset. Upset with Mac Fhirbhisigh's genealogy and upset with O'Donovan's coverage of Ossorian history. Shearman is best known for his Loca Patriciana (1878) - a solid and vital work in part, but not a great one. Error-ridden, oft rambling, apt to move back and forth between the ages without care for synchrony, and more than oft devoid of citations or even bare references. Loca Patriciana exposes Shearman as an historian standing reliant on what he thinks must be historically correct because, well.... it simply must be - no citations required!

While broaching the topic of 'the numerous sept of O'Brenan of Hy Dhuach', he declares, in not atypical Shearman fashion, 'the fact cannot be gainsayed that they are of the true regal descent of the Ossorians'. Sadly, Shearman's own facts are nowhere in sight, but more to pity is that he affords no opportunity to understand his thinking, that the facts might be discussed with him. And, as this article will demonstrate, the origins, genealogies, and acts of the Ó Braonáin Uí Dhuach are well worth discussion. There is no such criticism required for the 'History of the Brennans of Idough' (Brennan, 1979), and much of this section covers similar ground to that found there, but ready access to Brennan's book is outside the reach of most; there are, however, some minor corrections and additions, and some valuable discussion points.

But, to concur with Brennan, there is no evidence the Ó Braonáin were called the lords of Uí Dhuach at any stage before the twelfth century (Brennan, 1979). Shearman's assertion that Braonáin, the grandson of Cearbhall, was, in 912 AD, slain 'in Ui Dhuach' is gratuitous since the text of the Fragmentary Annals only states that he was slain, 'in the middle of his own fortress' (O'Donovan, 1860). Similarly embellished is the reference to the death of Donnchadh Mac Giolla Phádraig (Lord of Osraí), in 1039 AD; Shearman states his wife was 'the daughter of his kinsman O'Brenan Chief of Ui Dhuach', when in fact the manuscript he draws from (TCD MS 804) states only that 'O'Braonáin's daughter' was 'of Ui Dhuach' (Graves, 1850 and Brennan, 1979).

The topographical poems of Ó Huidhrin (O'Heerin)and Ó Dubhagain (O'Dugan) are cited as evidence that Ó Braonáin were lords of Uí Dhuach in pre-Norman times (Brennan, 1979). Still, this line of argument fails to convince because the prose of neither Ó Huidhrin nor Ó Dubhagain can be considered as primary sources - they were writing long after the fact having died in $1420 \mathrm{AD}$ and $1372 \mathrm{AD}$, respectively (O'Dubhagain, O'Donovan \& O'Huidhrin, 1862). However, a record in the Annals dated 1146 AD cannot be questioned concerning the rising status of certain O'Braonáin, although there is no sure association of them with Uí Dhuach:

'Gillaphadraig, the grandson of Donnchadh, lord of Osraighe, was killed by the O'Braenains, by treachery, in the middle of Cill-Cainnigh' (O'Clery, 1856).

An entry in Liber Primus Kilkenniensis (Otway-Ruthven, 1961), dated 1200 AD, intrigues but it does not refer to Ó Braonáin being lords of Uí Dhuach. The Latin text is translated 'the Obrenans burnt the castle of Comyr and the towns of Leylinn and Wellys', and the assumption is that these 'Obrenans' must be Ó Braonáin of Uí Dhuach because 'Comyr' (i.e., 
Caisleán an Chomair/Castlecomer) lies in Uí Dhuach and 'Leylinn and Wellys' (i.e., Seanleithghlinn/Oldleighlin and Uilis/Wells) are at the eastern border (Brennan, 1979).

Between ca. 1286 AD and 1295 AD, there are a series of records that relate to individuals by the name of Amhlaoibh (Auliffe) Ó Braonáin. Graves (1850) noted, based on a Pipe Roll record that is no longer extant, an 'Auliffe son of Melaghlin', who was living in 1286 AD, was fined by William Cadel; this record duplicated, but dated ca.1276 AD, notes the fine was $f 6$ 10s (Sweetman, 1877). Cadel served as Seneschal of Carlow from 1283-1289 AD (Hartland, 2003), making the 1286 AD date surely attested. In 1293 AD, 'Avelan O'Brenan' was fined 100s for 'transgression' (Sweetman, 1881) by William le Deveneys, who held several roles in the Irish judiciary (Devenish \& McLaughlin, 1948). Then, in 1295 AD 'Aulef Obrenan' is granted the King's peace 'for all trespass' relating to 80 cows (Sweetman, 1881), for which John FitzThomas FitzGerald (fourth Lord of Offaly and first earl of Kildare), was held responsible. This Amhlaoibh Ó Braonáin, therefore, was a tenant of FitzGerald (Brennan, 1979) and not so obviously any resident of Uí Dhuach.

These aforementioned records are invaluable because they not only provide accurate temporalities, they can also be compared and aligned with genealogies of persons named Amhlaoibh Ó Braonáin. The genealogies of the O'Braonáin of Uí Dhuach have been the subject of no small contention. Graves stated,

'Dr O'Donovan informs me that he never saw a pedigree of the O'Broenains of UiDhuach, except that given in the great genealogical work of Mac Firbis' (Graves, 1850, p.234).

Graves' reproduction of Mac Fhirbhisigh's pedigree provided to him by O'Donovan ascends from 'Auliffe Oge', the tenth in line from Cearbhall, and back; most notably, Cearbhall's father is named as Cu-Bladhma. Graves sought an independent authentication of the Mac Fhirbhisigh pedigree, that of the high authority vested in Sir William Betham, the Ulster King of Arms - and the pedigree was verified (Graves, 1850).

It was Mac Fhirbhisigh's designation that the father of Cearbhall of Uí Dhuach was CuBladhma that resulted in Shearman's indignation. Shearman offered nothing to support his belief that the father of Cearbhall of Uí Dhuach was Dúnghal, not Cu-Bladhma, perhaps being reliant on Hogan. Hogan had, in an earlier publication, argued against the Cearbhall mac Cu-Bladhma lineage, which he called a 'discrepancy between the pedigree of Mac Fhirbhisigh and the many other authorities' (Hogan, 1864). The 'many other authorities' that Hogan cites are the Four Masters (O'Clery, 1856), O'Donovan (O'Dubhagain, O'Donovan \& O'Huidhrin, 1862), and Keating (1732). But neither the Four Masters nor O'Donovan (or the sources O'Donovan cites) even venture to suggest the O'Braonáin Uí Dhuach descended from Cearbhall mac Dúnghal. However, Keating does.

Keating is not one known for his accuracy concerning either Irish pedigrees specifically or Irish history generally (Cunningham, 2004). Keating stated that the O'Braonáin of Uí Dhuach were derived from the same noble stem as the Mac Giolla Phádraig 'Kings of Ireland' and his pedigree of them states the O'Braonáin of Uí Dhuach and Clan Costigan both 'sprang' from Braonáin, the son of Cearbhall. But Keating is hopelessly incorrect regarding both the regal 
status of the Mac Giolla Phádraig and the origins of the Costigans, glaring errors that Hogan surely understood yet seemingly turned a blind eye to. Why, then, should Hogan, or anyone else, consider for one moment that Keating somehow demands an elevated consideration regarding the origins of O'Braonáin Uí Dhuach? Hogan has one further argument for maintaining the father of Braonáin mac Cearbhall was not Cu-Bladhma - that the latter's pedigree contains 'names unknown in the history of Ossory', but his position is weak because Mac Fhirbhisigh's ascent from Cu-Bladhma leads to Uí Failghi lineages - not exactly clans distant from Osraí.

After considering Shearman's non-existent case, Hogan's ill-contrived arguments, and Keating's flights of fancy, one must return to the single Irish genealogist who stands head and shoulders above all others. While a nineteenth-century review of Mac Fhirbhisigh's genealogies by Professor Eugene O'Curry (1861) was hyperbolic in its assessment, 'perhaps the greatest genealogical collection in the world', that of Eoin MacNeill (1921), 'by far the largest and fullest body of Irish genealogical lore', was not (Mac Fhirbhisigh \& Ó Muraíle, 2003). A review of Ó Muraíle's edition of the Mac Fhirbhisigh genealogies declares it, alongside O'Donovan's edition of the Annals of the Four Masters, one of the 'two greatest works that any modern Irish scholars ever accomplished' (Ó Canann, 2002). This, and that Dr John O'Donovan (Professor of Celtic Languages), 'the foremost Irish scholar of the nineteenth century' (Mac Fhirbhisigh \& Ó Muraíle, 2003) saw fit not to deviate from Mac Fhirbhisigh, is enough to put Shearman's and Hogan's criticism of Mac Fhirbhisigh, and their ill-founded insistence that the O'Braonáin of Uí Dhuach descend from Cearbhall mac Dúnghal, into clear perspective.

And for the default perspective, which must be with Mac Fhirbhisigh, and not elsewhere, the pedigree of O’Braonáin of Uí Dhuach from Amhlaoibh Óg is as follows:

'Amhlaoibh Óg m. Muircheartaigh m. Amhlaoibh m. Maoileachlainn m. Amhlaoibh $m$. Giolla Coimde m. Cearbhaill m. Duinnslébhe m. Congalaigh m. Braonáin $m$ Cearbhaill; sunna contreagad agus Ui Dhuinn' (Mac Fhirbhisigh \& Ó Muraíle, 2003).

It is 'sunna contreagad agus Ui Dhuinn', meaning 'here they converge with Ui Dhuinn', that is deeply problematic for adherents clinging onto the idea that O'Braonáin of Uí Dhuach were Osraighe, for the Mac Fhirbhisigh genealogies firmly situate the descent of Braonáin son of Cearbhall, son of Con-Bladhma, out of the Ui Dhuinn (O'Dunn), who descended from Riagáin, who was the grandson of king Flann dá Chongal, of the Uí Failghi. (Mac Fhirbhisigh \& Ó Muraíle, 2003). Plainly and simply put, Mac Fhirbhisigh did not consider the O’Braonáin Uí Dhuach were any close kin of Mac Giolla Phádraig Osraí - but, as already noted, he did consider they were kin of the Ó Beargdha of the Uí Failghi.

Finding a response to the apparent irrefutable genealogy provided by Mac Fhirbhisigh, on behalf of Shearman and Hogan, is not difficult - an alternative pedigree is provided by Cú Choigcrícge Ó Cléirigh (Pender, 1951), another giant of an Irish scholar and one of the Four Masters. Ó Cléirigh's O'Braonáin Uí Dhuach pedigree differs from Mac Fhirbhisigh's in three important ways. Firstly, it is headed 'Genelach Ua mBraonáin Ri Úa nDhuach'; secondly, from Amhlaoibh Óg to Cearbhaill is fourteen generations, inclusive, compared with Fhirbhisigh's eleven generations; and, thirdly, the annotation that follows the O'Braonáin 


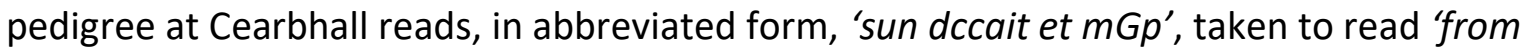
here spring mac Giolla Phádraig'.

Ó Cléirigh's use of Rí in his designating the O’Braonáin 'kings' of Uí Dhuach is rarely used elsewhere by him, hence, it appears out of place, and particularly so given the lofty elevation to $R i ́$ is not afforded by others. But it is the addition of two generations (Muircertaigh son of Muircertaigh) before Amhlaoibh Óg that causes Ó Cléirigh's pedigree to fail immediately, because the grandfather of Amhlaoibh Óg is, authoritatively, Amhlaoibh (living 1286 AD) - this recorded in Irish judiciary documents (Sweetman, 1877) and also in a Pipe Roll viewed by Graves (1850). Without ready access to Ó Cléirigh's manuscript (RIA MS $23 \mathrm{D}$ 17) it is impossible to further assess 'sun dccait et $m G p^{\prime}$ ', but that matters little. A pedigree found in Leabhar Muimhneach (The Book of Munster), which also designs to attach the lineage of Braonáin mac Cearbhall to Dúnghal, is annotated from who 'sprang the offspring of the Mac Braonáin Uí Dhuach' (Ó Donnchada, 1940). Therefore, at least two annotations in the pedigrees of the O'Braonáin of Uí Dhuach evidence positions different to Mac Fhirbhisigh, but the same as Shearman, and Hogan.

Perhaps if Mac Fhirbhisigh could respond to this dichotomy he would gently remind Shearman and Hogan that the great genealogists were not mere scribes or even outstanding historians; rather, they were highly trained and skilled in their specific discipline (Mac Fhirbhisigh \& Ó Muraíle, 2003). The confusion that comes when fusing fragments of manuscripts together, without consideration for the entire corpus of knowledge, belongs to the work of 'people like John Mac Solly and Richard Tipper' (Walsh, 1942); they were copyists worthy of credit concerning manuscripts such as Leabhar Muimhneach, but they are incomparable to Mac Fhirbhisigh, who 'knew so well' how to discern historical fact from fiction (Walsh, 1933; Walsh, 1942), being heir to the 'great learned tradition' of Irish genealogies, and 'its last great exponent' (Mac Fhirbhisigh \& Ó Muraíle, 2003).

A useful caution is found here, then, for the modern-day versions of scribes, those family historians who cause 'cut and paste chaos' (Fitzpatrick \& Fitzpatrick, 2020b) by duplicating records at the click of a mouse. Not that making errors during the duplication of genealogical records is some new thing. Those who might rush to O'Hart for his perspective on the pedigree of O'Braonáin Uí Dhuach will discover exactly that type of confusing replication. O'Hart's 'Brenan (No.1) Princes of Idough' pedigree has Braonáin nine back from Amhlaoibh Óg. And in 'cut and paste' fashion, O'Hart has an eerily near identical pedigree for his MacBrannen of Ui Dhuinn; this time Amhlaoibh Óg goes back to Braonáin in ten easy steps (O'Hart 1892).

But the disruption of Shearman's and Hogan's narrative goes further still; there is another possible reason why the O'Braonáin Uí Dhuach did not descend from Cearbhall mac Dúnghal - they could not because the line of Braonáin became extinct. 'The War of the Gaedhil with the Gaill' also known as 'The Invasions of Ireland by the Danes and other Norsemen', are narratives found in manuscripts first composed between 1103 AD and 1113 AD (Ní Mhaonaigh, 1996). Todd (1867), in conjunction with his translation of the manuscripts, developed various pedigrees to enable a greater understanding of the narratives; this included a genealogical table of the 'Descendants of Cearbhall, Lord of Ossory and the 
Danish King of Dublin', via both his sons and his daughters. Significantly, Todd has no descendants of Cearbhall out of a Braonáin lineage.

If Shearman and Hogan were upset with Mac Fhirbhisigh, surely they would have been apoplectic with Todd; but it appears neither were aware of his work. But is there any basis for suggesting the failure of Braonáin's line? Aside from genealogies, of which only Ó Cléirigh's require serious consideration, there is only a single record that mentions a son of Braonáin, and that is found in the Fragmentary Annals. Recorded there is that the 'son of Braenan, son of Cearbhall' was killed by Diarmait, Lord of Osraí (O'Donovan, 1860). This son of Braonáin is unnamed, but he is called Dúnagán by Ó Cléirigh (Pender, 1951); and with the use of Dúnagán the likely explanation for Ó Cléirigh's error becomes apparent.

Ó Muraíle states that Mac Fhirbhisigh finished the Laighin section of his genealogies in 1650, drawing mainly from the Book of Lecan, the Book of Ballymote, Rawlinson 502, the Book of Leinster, TCD MS 1298/H2.7 and 'unique material'. Ó Cléirigh's genealogies were written sometime between 1630 and 1664, and Ó Muraíle considers he and Mac Fhirbhisigh were probably known to each (at one stage they lived just 20 miles apart) and borrowed each other's material. It is considered more likely that Ó Cléirigh, the scribe, simply copied Mac Fhirbhisigh's genealogical material verbatim, as best he could, rather than Mac Fhirbhisigh accepting Ó Cléirigh's genealogical efforts uncritiqued (Mac Fhirbhisigh \& Ó Muraíle, 2003).

The personal name Dúnagán is found only twice in Leabhar na nGenealach, first in the pedigree of Síol Colla Mheinn (Oirghialla), and second in the genealogy of Clann Ghormáin (Laighin). In Leabhar na nGenealach, the genealogy of Ó Braonáin Uí Dhuach resides on the same folio (478) as the genealogy of Clann Ghormáin; in fact, the genealogies are closely adjacent, being 478.7 and 478.8 , on a folio that is quite congested. It is suggested that Cléirigh probably became confused while transcribing 'Braonán son of Cearbhall; here they converge with Uí Dhuinn' in a section of the folio that has 'Dúnagán son of Gormán, from whom is the family', perfectly alongside. Not having even close to the same depth of genealogical knowledge of Mac Fhirbhisigh that he could fall back on, Ó Cléirigh then made two errors by (i) converging the pedigree of Dúnagán with Braonáin, and (ii) then assuming his newly created son-father relationship must relate to the Cearbhall of Osraighe fame.

With no genealogical evidence left standing to support the Ó Braonáin Uí Dhuach stemming from Dúnagán, son of Braonáin, the context of the slaying of Braonáin's unnamed son by Diarmait becomes clearer. This was no ordinary nepoticide - we read he 'was piteously slain in the middle of his own fortress' (O'Donovan, 1860); piteous here indicating there was no just reason, and perhaps there was also a degree of treachery since Braonáin's son was in his own fortress. The furious response to the killing from Clann Dúnghal included that of Áed, who was the son of Cearball's daughter, Mór. The son of Braonáin was under Áed's tutorage, which means it was likely he had been living with Áed and/or his aunt Mór in a foster relationship, making the unjust killing all the worse. In addition, since he was being tutored and likely groomed to be a future chief, there is a certainty that the son of Braonáin was still young in years (Mclnerney, 2017), perhaps as young as twenty one years, his father having died $890 \mathrm{AD}$. If that were the case, and he died heirless, and with his death died the line of Braonáin, it would also give more all the more reason for the clan reacting so

furiously. 
At this juncture come questions. If the line of Braonáin went extinct, and if the Ó Braonáin Uí Dhuach stem from Ui Dhuinn, then what are the origins of the many Branans living today who trace to Cill Chainnigh and who share a Y-DNA connection with Fitzpatricks under haplotype R-A1506? From whom do they descend? Those answers come from an analysis of men of haplogroup R-A1506>BY140757, called Branan - and they do not trace solely to Ireland.

\section{R-BY140757 descendants of early Virginia colonists}

Haplotype R-BY140757 sits under R1b-L21, which is commonly referred to as the 'Celtic' haplotype (Lucotte, 2015), even though the emergence of R1b-L21, ca. 2500 BC (Cassidy et al., 2016; Cassidy, 2018), occurred long before the emergence of Celtic languages and what is considered classic Celtic culture in Ireland ca. 700-300 BC (Brown \& Ogilvie, 2009; Pope, 2021). The prevalence of R1b-L21 in the British and Irish Isles is high, ranging from an estimated $60-69 \%$ in Ireland, to $50-59 \%$ in the west of Scotland and Wales, to $11-20 \%$ in southeast England (Busby et al., 2011).

To date, putting surname switches aside, the occurrence of R-BY140757 in descendants of early Virginia settlers has only been found in men with surnames that sound like Branan. And one of the earliest records of a Branan in Virginia is found in 1665 when a Richard Bramham is granted land for the payment of passage for five persons to the Virginia Colony.

Richard Bramham, 240 acs. Rappa. Co., on N. side of sd. Riv. \& W. side of Totoskey Cr., 14 Oct. 1665. Beg. at head of land belonging to George Haslock, dec'd......Trans. of 5 pers: Symon Corneck. Wm. Cisell, John Brookes. Sarah Davies, Marke Hill (Nugent, 1979, p.89).

Land grants were made in exchange for the payment of passage to the Virginia for persons who, typically, became indentured to the person paying the passage. This practice was most common in the early years of the colonisation of Virginia and was a way to encourage settlement and provide labour for the wealthier colonists on the tobacco plantations (Robinson, 1957). Later records show Richard owned a tobacco plantation and tobacco, being a strong currency at the time, was used by him to make purchases and to pay fines and debts; this is evidenced for Richard in 1693, as follows, where there is also a surname variant, which became the common surname spelling for Richard:

Richard Branham of Farnham Parish, Richmond County to Thomas Gladman for 2000 Ibs of tobacco, 100 acres of woodland. Adjoins land of Samuel Coggins and land of John Sherlock. With consent of Deborah, 'my lawfull wife'. Witnesses: Wm Kissey, Robt Thornton. Signed Richard Branham, Deborah Branham (Sparacio \& Sparacio, 1991).

Richard's arrival to the colonies had taken place sometime before he received the patent for land, and this leads to the question of where he came from. He arrived prior to October 1665 , when he is recorded as a witness on a legal document.

(C) Copyright 2021 | All rights reserved | The Fitzpatrick Clan Society

Fitzpatrick, M., Fitzpatrick, I. (2021). The Similar-Sounding Surnames of Haplogroup R-BY140757. The Journal of the Fitzpatrick Clan Society 2, 1-41. doi:10.48151/fitzpatrickclansociety00421, 25 June 2021 
Thomas Dios of Westmoreland Co., VA gives power of attorney to friend Thomas Freshwater in respect to a suit to recover funds due him by Robert Smith. Wit: Richard Bramham and Samuel Bowin (Sparacio \& Sparacio, 1989).

There have been many unpublished references, made by family historians, which state Richard was from Yorkshire, England, but fully conclusive sources are not cited for this link. There is a baptism record for a Richard Bramham, dated 17 October 1648, in Monk Fryston (White, 1895), which fits a narrative that Richard's origins were in Yorkshire:

The family of Branham, or, as it is sometimes spelled Bramham, was a long resident in West Riding, Yorkshire (Jolliffe, 1893).

But if this assertion is based only on Richard's name and approximate year of birth, without considering alternatives, it could be a mistake; unfortunately, it is an option deemed as factual to many with family trees at genealogy websites, such as ancestry.com. However, there is another baptismal record that fits Richard Bramham's profile, that is if Richards's baptism was ever recorded; it is for Richard Bramham of St. Clements Danes, Westminster, dated 24 June 1645 (City of Westminster Archives Centre, 2021). This record supports a birth earlier than 1648 - the issue with a 1648 birth being it would mean Richard was only 18 years old when he arrived in Virginia, which was too young to hold land (Keim, 1968).

There are other connections that can be made from Richard's records in Virginia, the closest of which is through his wife Deborah, who was the daughter of George Haslock. Richard and George are mentioned in a record from 1665, which related to a dispute over the border of Haslock's land:

When they posed a similar question to Richard Branham, an Antient Man and Son in Law to Geo. Haslock, dec'd, Branham replied 'No, George Haslock was dead before I came into the Countrey' (King, 1966).

A connection between Richard and Thomas Freshwater is also evident:

4 May 1669. Thomas Freshwater by virtue of the power he had from his brother-inlaw Richard Branham, sold 240 acres of land to Henry Austine on the North site of Rappahannock River (Sparacio \& Sparacio, 1989).

Thomas Freshwater was married to Johanna, the sister of Deborah Haslock, and he and his wife appear on many court and land records. Richard Bramham was the Godfather to one of their sons.

3 May 1670. Richard Bramham gives to his godson and cousin Thomas Freshwater a two-year old heifer. Wit. Will. Lloyd, Edward Williams (Sparacio \& Sparacio, 1989).

When examining alternative Yorkshire or Westminster records for the surname Freshwater or Haslock there is nothing of note found in Yorkshire. However, in the London area, there is a baptism record for a Johanna Haslock, who was a daughter of George Haslock and Michelle Bramman, in the church St Lawrence Jewry (England Births \& Christenings, 2021), 
which is just one mile west from the church of St. Clements Danes. If Michelle Bramman was Richard's aunt, there is an obvious route for Thomas Freshwater jr. to be both his cousin and his Godson.

There are additional Virginia records, which provide detail into potential familial relationships. Richard's wife Deborah is mentioned in legal records as a power of attorney for him while he was still alive, which suggests Richard may have been travelling.

Debora Bramham gives power of attorney to 'my well-beloved friend William Sisson' to acknowledge 100 acres sold to Thos. Gladman. Wit. Thomas Freshwater, John Hill. Signed Debora Bramham. Richmond Co., 8 March 1693 (Sparacio \& Sparacio, 1991).

There are several records of the name Sisson in the Colonies, and it is of interest that children of a William Sissons are also found in the St. Clements Danes Church baptism records ca. 1650 (City of Westminster Archives Centre, 2021). The connections between the surnames Bramham, Haslock, and Sisson in records of Westminster churches find no equivalent in Yorkshire records of the same period, providing a reason to advance that Richard Bramham was more likely to have been from London (refer Appendix 1).

Richard's lines left Virginia to settle in Kentucky, and, in the 1800s, most of them are found in Scott County; some branches went into Illinois, Indiana, and Missouri. The descendants of Richard share ancestry from the thirteenth century (ca. 1200 AD) with men who have similar-sounding surnames (Brannan or Brannon) and who also trace their descent from colonial setters in Virginia; they belong to haplogroup R-A1506>BY140757>BY203414> FT69881>FT124531>FT70038, which arose before ca. 1680 AD. There are two key ancestors in these R-FT70038 Virginia lineages - Charon (Caran) Brannan and Kenyon Branan (refer Appendix 2).

The published lineages of Caran Branan are complex and at times confuse, and Caran's preNorth American origins are not certain. The first record that appears linked to Caran, which is oft-cited by his descendants, is a court document from ca. 1699:

Charon Brenhan, servant to George Davenport, being presented to this Court to have inspection into his age, is adjudged twelve years old and ordered to serve his said master or assigns (Sparacio \& Sparacio, 1991).

This court process was in place to reduce the number of children being brought to work in the Colony of Virginia as labourers. The record for Caran does not mean he was twelve years old, but he had at least attained that age; most males who went to the Colony as servants were fifteen to nineteen years old (Galenson, 1978). There is no evidence by which Caran's country of origin can be determined, and the records of George Davenport shed no light on where he may have originated either. Any attempts to conclusively base Caran's origins on either his given name or surname are fraught, since it is well recognised that from early colonial times until the nineteenth century, the spelling form of the surname was in the hands of clerks; many individuals with Brannan sounding surnames were illiterate (Brennan, 1979). 
However, what is clear is that Caran, an indentured servant on arrival, was of lower social status than Richard Branham. Caran's descendants settled in Virginia and North and South Carolina in the late eighteenth century, and many went on to claim lands in Georgia in the early nineteenth century. The connections in some lines are impossible to verify fully, however the vast number of historical records of the descendants of Caran shows the generally adopted spelling of the surname was Brannan, or Brannon.

There is no such difficulty verifying the lines that trace to Kenyon Branan; this via a family Bible and many land, census, and vital records from the early nineteenth century. 'The History of Wilkinson County' states:

Of the sturdy pioneers of Wilkinson whose strength of body was only exceeded by their strength of character may well be mentioned Caswell Branan (1807-1897). Born in Morgan County, Georgia, August 10, 1807, the son of James and Sarah Tommy Branan, both natives of Virginia, and grandson of Kenyon Branan, originally from Wales, he with his parents moved to Wilkinson in 1810 (Davidson, 1930).

Therefore, there is evidence enough that Caswell and James, his father, were born in Virginia and that Kenyon was Welsh; or is there? There comes a genetic disruption of the narrative that Kenyon was from Wales, in the United Kingdom, because the pattern of $Y$ DNA mutations in descendants of Caran and Kenyon indicates Caran was generationally senior (e.g., father, uncle, or grandfather) to Kenyon. Problematic here, but not fatally so, for his Welsh origins is that Kenyon was born ca. 1730 AD, and Caran's immediate descendants were born in the Colony. But maybe it is the Wales connection that misleads. Believe it or not, there is an estate called Wales in Dinwiddie County, Virginia, which lies approximately six miles west of Petersburg. The origin of the estate dates to ca. 1730 AD (Lancaster, 1936).

Caran's passage to Virginia was in 1695 when he was one of a group of ninety persons transported to the Colony, the equivalent headrights being a grant of 4,500 acres in King and Queen County, on the north side of the Mattaponi River (Nugent, 1979). The grant was made to Major Peter Beverley, but the land was deserted and re-granted to others. Although the exact details are unknown, the headright patent for Caran Branan was transferred to George Davenport, whose holdings were in North Farnham, Richmond County, some 65 miles northeast of where the Wales estate would be built.

Caran's connection to George Davenport leads to a possible association with Dinwiddie County, which emerged from Prince George County (Lancaster, 1936) where the Prince George Davenports had interests from the early eighteenth century (Davenport, 2007). But with most of the early Dinwiddie County records destroyed (The William and Mary Quarterly, 1915), it is little surprise that Branan connections with Wales, Virginia, cannot be found, even if they did once exist. Ultimately convincing, however, is the record of Kenyon Branan in the Bible of Miss Effie Cooper, which states he was of Virginia (Talmadge, WF Dykes \& Daughters of the American Revolution, 1926).

Without Y-DNA clues, the origins of Richard and Caran/Kenyon would likely have remained uncertain in perpetuity. But with Y-DNA clues, links can be made. Male descendants of 
Richard, who still bear the surname Branham, are haplogroup R-A1506>BY140757> FTA81953. Their closest Y-DNA matches, prior to the emergence of Richard's line, trace to Cill Chainnigh and the surname Brennan, are under two 'sibling' branches, viz., R-A1506> BY140757>BY203414 and R-A1506>BY140757>BY203414, with shared ancestry of the three 'siblings' from ca. 1200 AD. For the line Caran/Kenyon there is also a common ancestry to Branans in Cill Chainnigh, but the connection emerges later, ca. 1400 AD, being at R-A1506> BY140757>BY203414>FT69881 (refer Appendix 3). Making sense of R-BY140757 similar sounding surnames is, therefore, a complex business and requires an interrogation of early English records.

\section{The de Braham of Yorkshire}

Greater Braham and Little Braham are mentioned in several entries in the Domesday Book (https://opendomesday.org). In 1086 AD, they were held by various tenants in chief, including William de Percy, Gamalbarn, Gospatric (son of Arnketil), and Erneis de Burun. The original manor and village of Braham is lost but is now represented by Braham Hall (Fisher, 1954). Not to be confused with Bramham Hall, in West Yorkshire, Branham Hall is one mile east of Follifoot, in North Yorkshire (Figure 1). The family of de Braham trace their lineage to Hippolitus de Braham (Farrer \& Clay, 1955), who was possibly a descendant of the aforementioned Erneis de Burun. At the Domesday survey, Erneis de Burun held five carucates (approximately 600 acres) in Yorkshire as well as lands in Lincolnshire (Farrer \& Clay, 1955); he was also Sheriff of Yorkshire ca. 1080-1087 AD (Farrer, 1915).

Although it has not been possible to trace the descent of de Burun (Farrer \& Clay, 1955), there is a link between him and the de Braham family that stems from the Braham fee. Hippolitus de Braham appears in Yorkshire records ca. 1145-1160 AD, having granted six bovates (approximately 20 acres) in Middleton (Ilkley Parish, West Yorkshire), to the hospital of St Peter, York. Hippolitus was the father to at least three sons (Henry, Matthew, and Hugh) and two daughters (Flandrina, and Maud).

In 1166 AD, Henry, the oldest son and heir of Hippolitus, was in joint possession of a de Percy fee, and in 1167 AD, he had an interest in Braham. Henry had succeeded his father by at least $1175 A D$, although Hippolitus was living at that time. Along with his father, Matthew de Braham was a witness to a charter, issued ca. 1154-1175 AD, by Nigel de Stockeld, which gifted land and pasture to the hospital of St Peter, York. Hippolitus enfeoffed to Hugh, the youngest son, four carucates (approximately 480 acres) in Follifoot, Middleton, and Stubham (Ilkley Parish, West Yorkshire) no later than 1176 AD.

Hugh had several sons: Robert, Nicholas, Laurence, Walter, and Eneas. The latter is, perhaps, an indication of de Braham's descent from Erneis de Burun. Eneas de Braham, and his brother Robert granted lands in Middleton to the Augustinian priory at Bolton Abbey, West Yorkshire (Clay, 1930). From Robert's son, Peter come the family of Middleton of Stockeld. Maud de Braham married Arthur, son of Serlo de Westwick, with the gift of a portion of Middleton, and Flandrina de Braham was still living ca. 1234 AD (Farrer, 1914; Farrer \& Clay, 1955). 


\section{Figure 1: Location of Braham Hall in North Yorkshire}

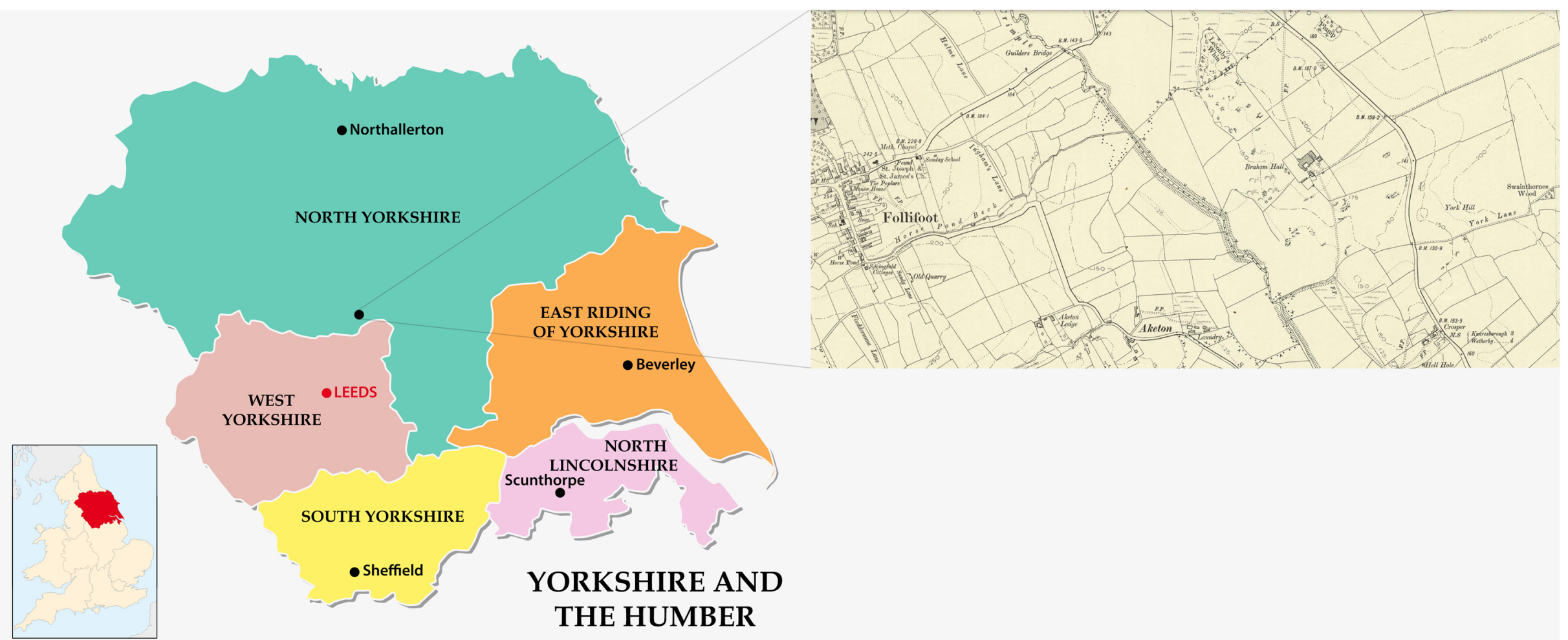

Braham Hall - early-attested site in the Parish of Spofforth.

Yorkshire and The Humber graphic by lesniewski

Use of digitised OS maps for non-commercial purposes is permitted under the Creative Commons Attribution-NonCommercial-ShareAlike 4.0 International licence.

(C) Copyright 2021 | All rights reserved | The Fitzpatrick Clan Society

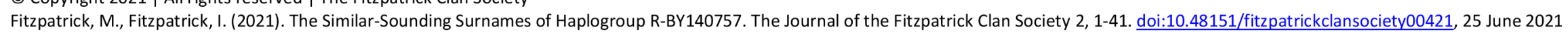


The de Braham (a surname sometimes recorded as Brenna, Bram, Braam, Brame, or Braime) were 'of considerable consequence during the Norman and succeeding ages' (Speight, 1894), and they continued to feature in early Yorkshire charters until the mid-fourteenth century. Their holdings in Braham eventually went to other families. Still, descendants of Hippolitus are found in nearby Follifoot, Middleton, Yeadon, and Spofforth: in 1311 AD, Simon de Braam granted land in Yeadon (Clay, 1924); ca. 1324 AD Matthew de Braam is witness to deed relating to Little Ribston, near Spofforth (Brown, 1914); in 1327 AD Matthew de Braam demised his tenement in Stockeld to the parson of St Michael's York (Clay, 1924); in 1333 AD Matthew de Brame was witness to a grant in Little Ribston (Stanley Price, 1955); in 1336 AD Matthew de Brame demised to Eustachia, widow of Sir Peter de Middleton (Sheriff of York, 1335 AD) lands in Stockeld, and he also witnessed a similar demise made by John de Caylii in 1339 AD. Then, in 1345 AD, John, son of Matthew de Brame is recorded as having loaned ten marks from Thomas, son of Sir Peter de Middleton (Clay, 1930).

From the end of the fourteenth century, de Braham records in the Yorkshire Charters are less common, but from Yorkshire Parish records, which become available ca. 1600 AD, it is evident that Braham lines were still extant in Spofforth Parish and that the surname, and similar-sounding surnames, was relatively widespread in Yorkshire (West Yorkshire Archive Service, 2021). There are, however, no apparent associations to be found that indicate any early de Braham of Yorkshire lines may have migrated to Ireland, that could explain a genetic association with Irish Branans.

\section{The de Braham of Suffolk}

The de Braham name occurs in many Suffolk records from the twelfth century onwards, particularly in the Parish of Brantham (Maxwell Lyte, 1894; Rye, 1900). Within the parish is Brantham village and, approximately one mile south, is Braham Hall (Figure 2). Situated near Cattawade, Braham Hall is at Suffolk's county border with Essex. The manor, where there remains evidence of a medieval moat (Gardner, 2003), was held by the de Brahams from the thirteenth century; it remained in possession of the de Brahams until the death of Elizabeth, heiress of Sir John de Braham, shire knight of Suffolk, in 1478 AD (Illingworth, 1818; Blomefield, Parker \& Miller, 1805; Copinger, 1910; Roskell, Clark \& Rawcliffe, 1993).

The earliest records for the de Braham name in Suffolk pertain to Eustace de Braham, who is found in various deeds from ca. 1150 AD. Eustace is extant in records until 1202 AD, and he is referred to as the son of Theobald and brother of Fulco (Tanner, 1787; Palgrave, 1835; Lyte, 1894; Pipe Roll Society, 1890; Stenton, 1952; Sharp, 2014). In a late twelfth-century grant of a salt house in Brantham to the canons of Dodnash Priory, Eustace declared himself, in the fashion of the day, a 'friend of all men, French and English, present and future'; witnesses to that grant included Sir Roger Bigod (second Earl of Norfolk), Thomas de Braham, and Hugh de Braham (Harper-Bill, 1998). Although nothing further is discoverable regarding the earlier origins of the de Brahams of Suffolk, the connection with the Bigod family is an important one. Prominent among late twelfth and early thirteenth century de Brahams of Suffolk was Roger, son of Eustace (Harper-Bill, 1998), who appears as the seneschal of Sir Roger Bigod from 1198 AD (Dodwell, 1952). Roger de Braham was the successor of Eustace (Brown, 1987), and two other de Brahams (Hugh and Thomas probably those aforementioned, and perhaps Roger's brothers) were members of the 
baronial garrison at Bigod's Framlingham Castle during the siege of 1216 AD, which followed Bigod's role in the rebellion against King John of England, the year previous (Brown, 1951).

The relationship between the Bigod and de Braham families can be evidenced severally throughout the thirteenth century, but it is their involvement in matters of law that catches the eye. Randolph de Braham is a witness to the charter, ca. 1221-1225 AD, of Hugh Bigod, a son of the third Earl of Norfolk, relating to the grant of Stockton manor to Hamo Lenveise (Morris, 2005). This Hugh Bigod was Justiciar of England (1258-1260 AD), and it was the connection between the Bigod and de Braham families that most likely led to Randolph de Braham also entering the services of the Judiciarship of England. In 1265 AD, Randolph de Braham is recorded as hearing a plea with Hugh le Despenser (Justiciar of England, 12631265 AD) (Maxwell Lyte, 1894).

From the late thirteenth century there are many de Brahams who can be traced to Suffolk. Notable are the aforementioned Sir John de Braham, knight, who served in several overseas campaigns (ca. 1370 AD - 1404 AD), including those in France, Ireland, Portugal, and Spain, and William de Braham, who served in France in 1370 AD under William Ufford (Second Earl of Suffolk) (The Medieval Soldier, 2021). But during this era de Brahams also appear throughout the south-eastern counties of Norfolk, Essex, Hertfordshire, Middlesex, and Bedfordshire (see, for example, Dawes et al., 1970; Story-Maskelyne \& Maxwell Lyte, 1898; Story-Maskelyne \& Maxwell Lyte, 1915; Sharp, 1904; Sharp 1906; Sharp \& Stamp, 1908; Stamp et al., 1921; Stamp et al., 1954). Many lines appear to have prospered, and it comes as little surprise they are found in high positions of London Society from the seventeenth century; the most prominent was Sir Richard Braham, MP for Windsor, whose grandfather was of Suffolk origin (Henning, 1983). Of significance to article is how the high-ranking roles of various de Braham of Suffolk origins - in governance, the military, and in the judiciary appears very likely to have found a parallel expression in Éire.

With the partition of Laighean in 1247 AD among the five daughters, or their heirs, of William Marshall (first Earl of Pembroke) came a 'galaxy of successors to the Marshal lordship of Leinster' (Frame, 1998). This led to possessions in Éire for the Bigod family via Marshall's eldest daughter, Matilda, who had married Hugh Bigod (third Earl of Norfolk). Hugh and Matilda's son, Sir Roger Bigod (fourth Earl of Norfolk and the Earl Marshal), gained the additional title of Lord of Carlow (Frame, 1998). Hence, compared with the de Braham of Yorkshire, a potential connection between the de Braham of Suffolk and Ireland can easily be imagined.

And there is another connection between the de Braham of Suffolk and Laighean that can readily be demonstrated. The heir of William Marshall's second daughter, Isabel, who had died in 1240 AD (her portion of Laighean being the lordship of Kilkenny) was her son, Richard de Clare, the sixth Earl of Gloucester (Altschul, 1965). Following the Norman conquest of England, Richard, son of Count Gilbert of Brionne, came to hold large estates, including the lordship of Clare in Suffolk (https://opendomesday.org), which sits on the River Stour, some fifty miles north-west of Cattawade. In the twelfth and thirteenth centuries, the de Clare possessions in England, Ireland, and Wales more than doubled, and the family's land expansions included everything from small, individual manors to great honours, such as Gloucester (Ward, 1962). 


\section{Figure 2: Location of Braham Hall in Suffolk}
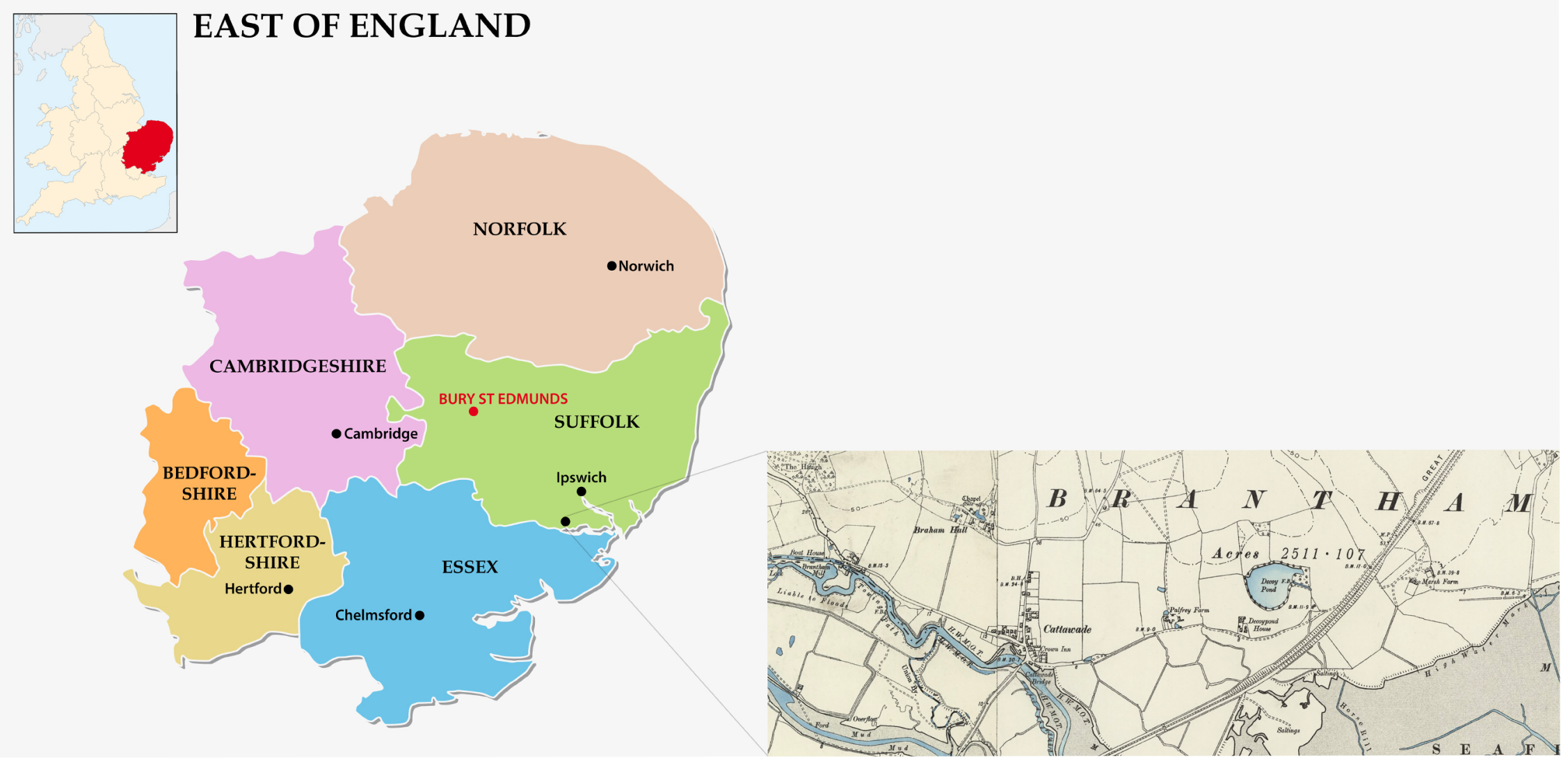

Braham Hall - Monument record BNT 002.

East of England graphic by lesniewski

Use of digitised OS maps for non-commercial purposes is permitted under the Creative Commons Attribution-NonCommercial-ShareAlike 4.0 International licence.

(C) Copyright 2021 | All rights reserved | The Fitzpatrick Clan Society

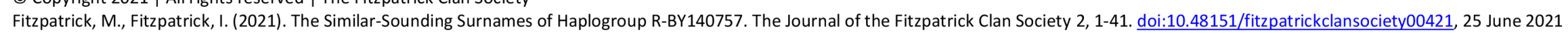


The de Clare Suffolk interests grew to include Braham, which Gilbert de Clare (seventh Earl of Gloucester) held for a knights' fee (Sharp, 1906), although it is not known when the de Clares came into possession of Braham, since the only complete record of Clare lands dates from the early fourteenth century (Ward, 1962). Certainly by $1315 \mathrm{AD}$, at an inquisition post mortem of Gilbert de Clare (eighth Earl of Gloucester), William de Braham held Braham in knights' fee. (Sharp \& Stamp, 1908), but it is likely that by the middle of the thirteenth century that the de Brahams of Suffolk had entered the orbits of the de Clares; and the de Clares were the newly appointed lords of Kilkenny.

More than 950 years after the Norman conquest of England, Y-DNA analysis is uncovering the patrilineal mix of the Norman nation. Generally considered Norsemen, 'pagan barbarian pirates from Denmark, Norway and Iceland' who settled in the Frankish kingdom (Britannica, 2015), it is evident that some Norman descendants are, by genetic definition, Celts (Karakachoff et al., 2015). One such Celtic-Norman line appears to be found in the 'genetic father' of R-BY140757, known as R-A1506. With this understanding it is possible to make compelling connections between the Branan surnames in Cill Chainnaig, Virginia and Suffolk, and then uncover a Norman line in Cill Chainnaig from whom R-BY140757 descendants may share common ancestry with. But first it is necessary to understand more of the likely origins of R-A1506.

\section{Haplogroup R-A1506}

High frequencies of R1b-L21 are not exclusive to the British and Irish Isles. R1b-L21 also finds a significant expression in several French regions. An analysis of approximately 2600 men from West-Europe (including England, but not Ireland, Scotland, or Wales) found the highest R1b-L21 frequency was found in Bretagne (29\% of all Bretons), followed by London (21\%), Paris (17\%), and northern Portugal (11\%); the Paris result due to 'Bretons' massive immigration towards the Capital since the beginning of the twentieth century' (Lucotte, 2015). In addition, R1b-L21 sub-haplotypes are also found elsewhere in West-Europe, such as Spain (Martínez-Cruz, 2012) and the Netherlands (Altena, 2020).

More granular analyses of human remains from Ireland has found markers of R1b-L21 subhaplogroups, dated as Early Bronze Age, that are at least four mutations downstream of from R1b-L21 (at R1b-L21 ... DF13) and up to seven mutations downstream (R1b-L21 ... DF13 ... Z16294), from as early as 2286-2039 BC (Cassidy et al., 2016; Cassidy, 2018). Similarly, R1b-L21 sub-haplogroups are also evidenced in ancient samples from outside the Isles; R1bL21 ... DF13 ... DF21 ... FGC58887 (at least nine mutations downstream of R1b-L21) is found in the south of France ca. 2195-1922 BC (Brunel et al., 2020). These analyses provide a gauge for when early R1b-L21 sub-haplogroups were emerging in Ireland and West-Europe, i.e., approximately $2500 \mathrm{BC}$.

Although it is helpful to know that certain R1b-L21 sub-haplogroups have an ancient expression in Ireland, any idea that ancient 'Irish haplotypes' can be rigidly defined at ca. 2500 BC can easily be disrupted. For example, under R1b-L21 ... Z39589, there are cousins RM222 and R-S310, who share ancestry from ca. 2000 BC. The former are referred to as Irish Type I (or Northwest Irish; Moore et a., 2006), and from the latter purportedly emerge the Royal Stewarts, whose origins at the time of the Norman conquest of England was Bretagne 
(Paul, 1904). Hence, the 'genetic proximity between Bretons and Irish' among Ychromosome haplogroups is well recognised (Karakachoff et al., 2015). Still, any exact understanding of where R1b-L21 sub-haplogroups may have originated is complex because the migrational movements of ancient Celts was dynamic and not unidirectional (Fitzpatrick, 2018); there was a continuous coming and going of individuals and small groups (Pope, 2021).

While certain ancient R1b-L21 haplotype sub-groups, without doubt, have a greater expression in Ireland, no such 'Irish haplotype' definition applies to the major ancestor of R-A1506 under R1b-L21, which is R-FGC5494. Using root-to-tip methodology (Drummond, 2003) for SNP node dating, lineage branching patterns, and other data, a leading researcher of R-FGC5494 has determined that there is no evidence to suggest R-FGC5494 subhaplogroups arose in the Isles prior to the migration period, ca. $600 \mathrm{AD}$. That late arrival, the sub-haplogroup distribution patterns, and the absence of R-FGC5494 haplogroups in ancient Isles DNA, also suggest that R-FGC5494 surviving lineages have a Germanic tribal history. Hence, it is considered the vast majority of R-FGC5494 lineages in the Isles descend from Vikings, Saxons, Franks, or Normans (J. Wigand, pers.comm., 16 June 2021).

That R-A1506>BY140757 men with Branan surnames occur in discreet sub-branches that originated in both England and Éire ca. 1200 AD evidences either an early migration of the haplotype in English who carried it to Éire, or in Irish who carried it to England. This article explores only the former since there is, by far, a much clearer understanding of what the obvious historic pathway was ca. 1200 AD - viz., the invasions and settlement of Normans in Éire (Otway-Ruthven, 1980). And one settler line were de Braham by name.

\section{The de Braham of Cill Chainnigh}

In the same era that de Braham of Yorkshire and de Braham of Suffolk were notable families, men with exactly the same surname appear in Cill Chainnigh, and they are of no less status than their namesakes in England. Several records calendared in the Ormond Deeds (Curtis, 1932) pertain to de Braham, who act as witnesses in various land transactions and other legal matters. Most notable is Sir Robert de Braham, who in 1250 AD, when acting as a witness to a grant by John the son of Vincent de Everus to Roger de Penbroc of lands in Domhnach Mór (Donaghmore), is named as the Sherriff of Cill Chainnigh. Robert was also recorded as Sheriff ca. 1255 AD, having in his custody a person found coining (Sweetman, 1875). The appointment of Robert de Braham can only have been made by consent of Richard de Clare (the Lord of Kilkenny), and natural logic dictates this probably came about due to earlier family connections forged in Suffolk.

By 1263 AD the tenure of Robert de Braham as Sheriff was over; his successor was Sir Geoffrey de Forestall (White, 1936). Robert de Braham and Geoffrey de Forestall had undoubtedly been acquainted with each other from at least 1250 AD. In 1277 AD, both were witnesses to two grants of lands in Corbally in Tulach Ruáin (Tullaroan) parish to Thomas de Lega. Adjacent to de Lega's land was 'the land of Henry de Braham', and in 1286 AD Thomas de Lega received another land grant in Corbally, which was also adjacent to Henry de Braham's lands in Dámach (Damma; Figure 3); this time the witnesses were three de Braham - Sir Robert, John and Henry (Curtis, 1932). 


\section{Figure 3: Location of Dámach in Cill Chainnigh}
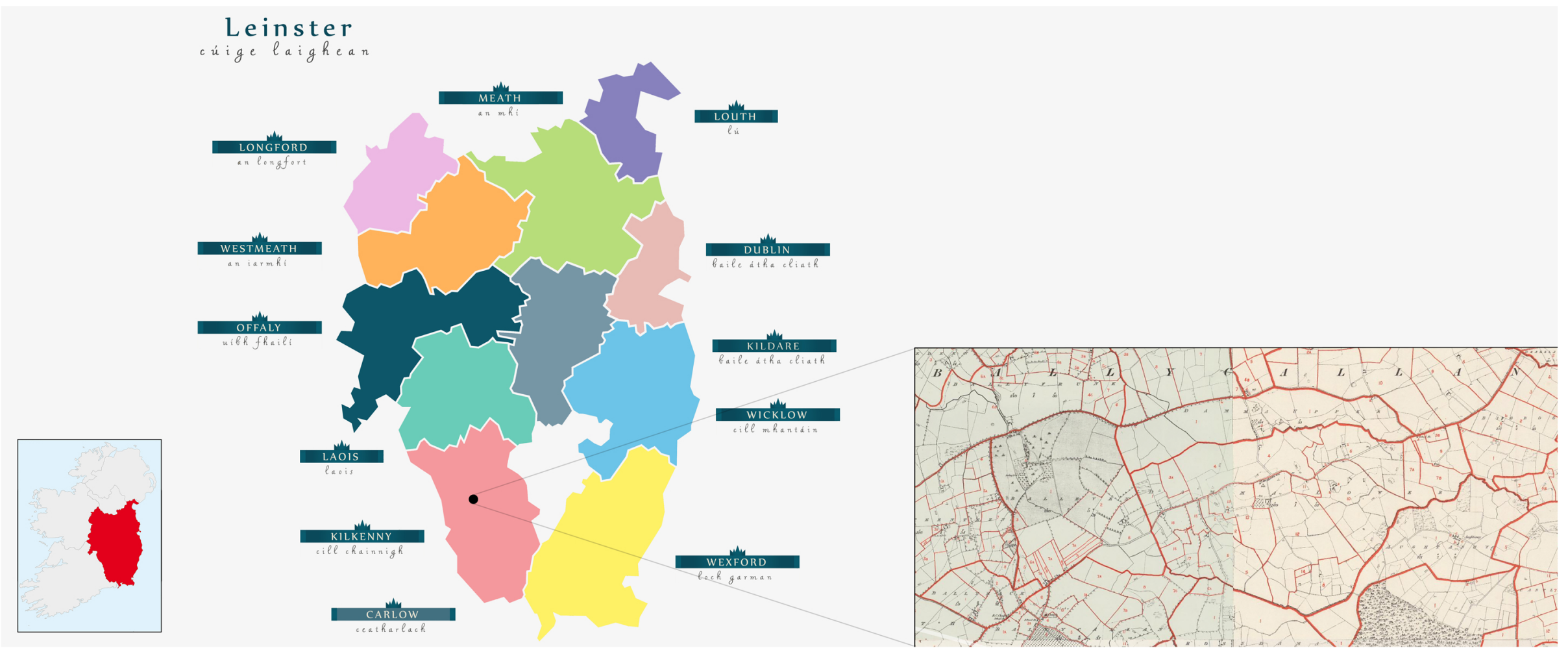

Dámach - Archival records.

Laighean graphic by Ingo Menhard

OS map imaged from Griffith's Valuation Ask About Ireland

http://www.askaboutireland.ie/griffith-valuation: accessed 7 June 2021; OMS Services Ltd, Eneclann Ltd and the National Library of Ireland.

(c) Copyright 2021 | All rights reserved | The Fitzpatrick Clan Society

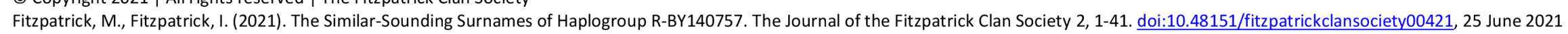


It was during this era that Sir Robert de Brahams's focus shifted from the military to the judiciary, the backdrop being that from 1176 AD, during the reign in England of Henry II, there came changes to the judicial system in England. This led to the appointment of greater numbers of justices (i.e., judges) to travel in circuits to hold court and preside over pleas (i.e., legal cases), both civil and criminal; the circuits and courts were known as Eyres, and those on the circuit were referred to as itinerant justices. Ireland lagged in progressing such judicial appointments and in 1221 AD only had one itinerant justice, but by 1253 AD it is evident more justices had been appointed (Sweetman, 1875). In addition, the Court of Common Pleas (i.e., those cases not involving the monarch), also known as 'The Bench', was active in Éire from ca. 1276 AD (Ball, 1927).

Surviving records of the English judiciary greatly increase during the reign of Edward II (1272-1307 AD), and many Irish records have been captured in the 'Calendars of Documents, Ireland' (Sweetman 1875; Sweetman 1877; Sweetman 1879; Sweetman 1881; Sweetman 1886) and 'Calendars of the Justiciary Rolls of Ireland' (Brand \& Getzler, 2012; Mills, 1905; Mills, 1914; Wood, Langman \& Griffith, 1905). The appearance of Sir Robert de Braham as a witness to Irish charters from 1277 AD (Curtis, 1932) coincided with his appointment, under Edward I, as a Justice of Common Pleas in 1276 AD (Sweetman, 1877). Robert de Braham is recorded as being an active justice and receiving payment for fees to maintain him in his office until 1285 AD (Sweetman, 1877; Sweetman, 1879; Ireland, 1904). When summoned to the Bench between 1286 AD and 1288 AD, Sir Robert de Braham did not appear and was fined accordingly (Sweetman, 1879); hence, it considered he died ca. 1288 AD. General Eyres ceased with the onset of Anglo-French hostilities in 1294 AD, after which only one-off visitations occurred in 1299 AD and 1302 AD (Brand \& Getzler, 2012). Another Robert de Braham is recorded as a justice itinerant in 1302 AD (Mills, 1905), and he is considered to be the son of Sir Robert de Braham (Ball, 1927).

Based on the dates of various records, it is not unlikely the aforementioned John and Henry were also sons of Sir Robert Braham. In addition to the Thomas de Lega land grant of 1286 AD, John and Henry are found as witnesses to a 1309 AD grant by Henry Brun of land in Tulach Ruáin to John fitz John (Curtis, 1932). And, there are records of de Braham land holdings near Tulach Ruáin. In an inquisition post mortem of Joan of Acre, the daughter of King Edward I of England, and wife of Gilbert de Clare; in 1307 AD, it is recorded that 120 acres of Joan's land in Dámach were held by John de Braham (Sharp \& Stamp, 1913; Sweetman, 1886). And in 1314 AD Thomas de Braham granted 29 acres of land in Baile Bhrabastún (Brabstown) to John fitz John as payment for John's enfeoffment (Curtis, 1932). This Thomas is also found earlier, in 1306 AD, with half a carucate (approximately 60 acres) in Clárach Uachtarach (Clara Upper) in the Barony of Gabhrán (White, 1932).

The connection between Dámach and the stewardship of Kilkenny castle existed on either side of Henry and John de Braham's land tenure. After the death of William Marshall, Henry III of England committed the former Earl of Pembroke's lands and castles in Ireland to Walerand Teutonicus. In 1231 AD Henry III mandated Walerand be delivered Kilkenny castle by the constable, else Walerand would 'endeavour to take possession'; the tension due to the fact Hamo le Gras intended to travel to Éire to prevent that happening - and that due to the directive of Richard Marshall, heir of Earl of Pembroke, who was a 'liege man of the King 
of France', and Henry's enemy (Sweetman, 1875). It is apparent Walerand did succeed in taking possession, and in 1247 AD Franco Teutonicus, a son or brother of Walerand, was holding Dámach for one-tenth of a knights' fee (Brooks, 1950). Seventy years later, in 1317 $A D$, the heir of Robert de Braham's successor as the Sheriff of Kilkenny, Sir Geoffrey de Forestall, still held Dámach's fee (Brooks, 1950).

Hence, it is apparent the de Brahams were domiciled, after they landed in Éire, on lands bounded by Baile Bhrabastún, in the modern-day parish of Tulach Ruáin, and Dámach, in the modern-day parish of Baile Uí Challáin (Ballycallan), which is five miles to the southeast. And it is also possible to closely approximate when Robert de Braham arrived in Éire; between 1247 AD, and the partition of Laighean, and 1250 AD, when he was appointed Sheriff of Kilkenny.

There is one further record in the Calendar of Ormond Deeds that refers to the de Braham; this relating a grant of 20 acres of land in Stachcan by Richard de Pencoyth to Roger de Braham, and his heirs, dated 1273-1287 AD. Stachcan is not readily identifiable but based on the array of witnesses, and what other deeds they witnessed, and that the infamous de Pencoyth had lands in An tInbhear Mór (Arklow) (Brooks, 1950; Frame, 1972), the most likely location of Roger and his heirs was Scaratanach, Cill Mhantáin (Scratenagh, Wicklow); any connection with the de Braham of Tulach Ruáin is difficult to confirm.

The remainder of fourteenth-century intrigues with respect to de Braham in Cill Chainnigh. The surname ceases to occur - but did it morph into a Branan, a more Gaelic sounding form? Thomas Brennan argues for an early example of a corruption of an Irish surname when he discusses the appearance of 'Brennans' in the boroughs of Cill Chainnigh from ca. 1365 AD, stating these were O'Braonáin who had been displaced from Uí Dhuach (Brennan, 1979). Brennan's case for a surname adaptation has merit, but definitively linking O’Braonáin Uí Dhuach with Branans of Cill Chainnigh, simply based on it being a similar-sounding surname, is fraught because Branan surnames emerged severally.

The individual Brennan (1979) mentions is William, who is recorded in the Ormond Deeds as the treasurer of the liberty of Cill Chainnigh in 1365 AD and 1375 AD, and in the Red Book of Ormond in 1375 AD. William appears as O'Brenan in the earlier record, and Brenan in the later ones (Curtis, 1934; White, 1932), but a case for William being an O'Braonáin is difficult to build on a single example. Of the several 'Branans' in the boroughs of Cill Chainnigh recorded in Liber Primus Kilkenniensis the surname spellings are either Brenan or Brynnan, not one is O'Brenan, although their occurrences are all after the promulgation of the Statutes of Kilkenny in 1366 AD.

The Statutes of Kilkenny were a response to the increasing Gaelicisation of the English in Ireland, many of whom had taken to the 'manners, fashion and language of the Irish enemies' (Curtis \& McDowell, 1968). MacLysaght (1985) stated the Statutes of had 'no bearing on the use of Mac and $\mathrm{O}$ ', and that was little pressure for Irish to 'give up' surname prefixes until the seventeenth century. This despite the decree being: 
'that every Englishman shall use the English language and be named by an English name, leaving off entirely the manner of naming used by the Irish' (Curtis \& McDowell, 1968, p. 53).

Clearly implicit here is that by 1366 AD some English had been doing precisely that adopting Irish styles of names. Hence, it becomes a two-choice scenario for William Branan of Cill Chainnigh: was he an Irishman who dropped the O, or of Gaelicised English stock, who first adopted an $\mathrm{O}$ only to drop it again later? The latter gains more traction because in 1365 $A D$, before the enactment of the Statutes, William's first name is a Norman first name - this fact not lost on Thomas Brennan 'because Norman Christian names were not in use among the Irish at this early date' (Brennan, 1979).

What is also clear is the bearers of Branan in Cill Chainnigh town were 'surprisingly' 'peaceful, and anglicised' (Brennan, 1979) since nothing else could have sufficed. The O’Braonáin Uí Dhuach, now known to be Uí Failghi, had demonstrated some willingness to negotiate peace with their Norman overlords ca. 1317 AD (Tresham, 1828), but they were neither entirely peaceful nor anglicised in this era, a fact attested since they had slain Simon Purcell, sheriff of Kilkenny, and 'about 20 others' in 1327 AD, and waged war against Caisleán an Chomair (Castlecomer) in 1329 AD (Butler, 1849). In 1359 AD they entered into a military treaty with James Butler (second Earl of Ormonde) (Graves, 1850) for their engagement 'against any of the English and Irish outside of peace and faith in the king' (Graves, 1850), but by 1385 AD O'Braonáin were at war with each other, with one faction in rebellion; Diarmait Ruadh O'Brenan and John Ruadh O'Brenan, along with Henry O'Logan, had killed Tadhg O'Brenan. Thomas St Leger was recompensed ten marks for the delivery of the trio to gaol, where they were sentenced to death and executed (Tresham, 1828). In such a climate, could one of the O'Braonáin Uí Dhuach have ascended to the highest role in the Cill Chainnigh treasury?

An alternative, and more ready, view here is that the Cill Chainnigh town Branans in the fourteenth century were not displaced O'Braonáin Uí Dhuach, but were out of a Norman line and were, quite naturally, living and working in a Norman town. The aforementioned William, treasurer of Cill Chainnigh in 1365 AD (Curtis, 1934), appears not long after the last mention of de Brahams in historical records of Cill Chainnigh. Hence, it is considered that William Branan was not mere Irish. His fellow witnesses, or participants, in a 1375 AD land concord were as high-ranking Cill Chainnigh individuals as could be imagined: Edmund Mortimer (third Earl of March) and James Butler (second Earl of Ormonde), between whom the agreement was made; Patrick de la Freigne, knight, and seneschal of Kilkenny; and, Fulc de la Freigne, the sheriff of Kilkenny - unlikely company for an O’Braonáin Uí Dhuach.

Also, William Branan was educated - a town treasurer who could read and write, which is not so easy to imagine if he was from O'Braonáin Uí Dhuach. There were significant roles taken by other, some no doubt similarly educated, Branans in Cill Chainnigh throughout the fourteenth and fifteenth centuries, and Liber Primus Kilkenniensis details several (OtwayRuthven, 1961). Patrick, Geoffrey, John, and Thomas Brenan were burgesses of Cill Chainnigh in 1383 AD; John and Thomas were glovers; and in 1391 AD Robert Brenan is one of four watchmen named - Robert was also appointed watchman in 1405 AD when he is, additionally, called a cleric. In 1403 AD and 1405 AD, John Brenan is named as a highly 
ranked elected official (portreeve) for the district of Irishtown, and, in 1406 AD, as mainpernor (i.e., a guarantor that a prisoner would appear before the court) for Cill Chainnigh gaoler, Henry Mortyn. Janyn Brynnan, a glover, is mentioned as a tax assessor in 1409 AD, and it is likely he is the same individual as John Brenan, merchant, who in 1417 AD was among the city's 'second twelve' - at that time Cill Chainnigh was a borough town, governed by an elected corporate body of twelve 'upper' and twelve 'second' burgesses (Prim, 1864). And in 1411 AD Peter Brynnan, a carpenter, was a tax collector - his surname and Janyn's being early examples of spelling variants, which came about via their similar sounds. Serjeant Walter Brenane was a Cill Chainnigh tax collector in 1420 AD and 1421 AD; in the latter record he is Walter OBrenan and appears with Serjeant Philip Brenane (Richardson \& Sayles, 1947)

Hence, there is a sense of permanence of the de Braham, later not implausibly known as Branan, in Cill Chainnaig from 1250 AD; they did not fade away but continued to take governance roles that were similar to those taken immediately after their arrival in Éire. Could it be that those de Braham were the ancestors of R-BY140757 men in Éire? A detailed and in-depth Y-DNA analysis, in conjunction with a broad critical review of historical records from Éire, Virginia, Yorkshire and Suffolk, says it is a possibility worthy of consideration.

\section{Explaining the R-BY140757 haplotree}

Appendix 3 provides the current R-BY140757 haplotree with the root at R-A1506, which emerged ca. 1120 AD. To date the only sibling of R-BY140757 is R-A1496, which has three branches - R-A1488, R-FT12974, and R-FT109894. R-A1488 is not surname-specific, being characterised by multiple surnames, notably Costigan, FitzGerald and Fitzpatrick. R-FT12974 is dominated by the sub-group R-FT12563, which is specific to the surname Dalton, that diverges with its sibling R-FT109894 (surname Purcell). R-FT109894 contains a single surname, Hennessey.

The three branches of R-A1496 emerged ca. 1400 AD and contain a common origination elements that are unrelated to geographic locations or paternal surnames. Rather, several of the sub-haplogroups of R-A1496 correlate with clerical lineages that emerged in the early fifteenth century. The forthcoming articles, 'Origins and descendants of R-A1496: A NormanIrish haplotype', and 'The Clerics of the Mac Giolla Phádraig', explore the relationships between R-A1496 surnames, which are complex and result in significant disruptions of dominant historical narratives, such as those of the Fitzpatricks of Osraí.

In contrast, there is little evidence the sub-haplogroups of R-BY140757 are clerical, and this provides clues as to the differences in lineage development after the divergence of $\mathrm{R}$ BY140757 and R-A1496, respectively, under R-A1506.

\section{Conclusions: conclusive and otherwise}

Having set out to critically review the history of Ó Braonáin Uí Dhuach, assisted by the focusing lens that is a twenty-first-century Y-DNA analysis, it is clear there are multiple factors that give reason to the challenge the traditional, dominant narratives of Ó Braonáin Uí Dhuach. 
That Ó Braonáin emerged in Uí Dhuach in the ninth-century was a result of their longstanding struggle for that desirable territory of Osraí. But the most authoritative genealogy of Mac Fhirbhisigh indicates the Ó Braonáin Uí Dhuach did not descend from Braonáin, son of Cearbhall, son of Dúnghal, of Osraí - that line appears to have become extinct. The Ó Braonáin Uí Dhuach were not Osraighe, rather they descended from Braonáin, son of Cearbhall, son of Cu Bladhma, of the Ui Dhuinn, of the Uí Failghi. And with that realisation, the origins of Branans living today who trace to Cill Chainnigh, and who share common paternal ancestry with Fitzpatricks under haplotype R-A1506, are disrupted.

Further disruption comes from Y-DNA analysis of descendants of the seventeenth-century Virginia colonist Richard Branham, who belong to haplogroup R-A1506>BY140757> FTA81953. Although it is not fully certain, Richard more likely came from the de Braham of Suffolk rather than the de Braham from Yorkshire. It was probably the connection between the Suffolk de Braham and the de Clare Earls of Gloucester, who became lords of Kilkenny, that provided a ready route of entry for the de Braham who are found in Cill Chainnaig from the thirteenth century.

The key figure among the Norman settler family was Robert de Braham, who arrived in Cill Chainnigh ca. 1250 AD; he was Sheriff of Kilkenny and, later, a justiciar. Robert was probably the progenitor of de Braham who held lands from the de Clares in Dámach, Baile Bhrabastún and Clárach Uachtarach in the fourteenth century. That the surname de Braham may have adapted to a similar-sounding surname, Branan, which is found in fourteenthcentury records for Cill Chainnaig, is not an unreasonable consideration given the Gaelicisation of Normans during that era.

A synthesis of all the factors mentioned above leads to the determination that the similarsounding Branan surnames of haplogroup R-BY140757 probably stem from a Norman lineage. This finding has implications for those haplogroups with common ancestry to RBY140757, i.e., those under R-A1506, among which are found the surnames Costigan, Dalton, FitzGerald, Fitzpatrick, Hennessey, and Purcell.

\section{Acknowledgments}

The authors thank Diane and Paul Branam, Clarence Brannon, Marlene Brannon, Shirley Hok and Jim Wigand for their very helpful inputs.

This article is dedicated to the late Professor Richard Branham, whose pioneering work on the English Brahams pointed us in the right direction. 


\section{References}

Altena, E, R Smeding, KJ van der Gaag, M Larmuseau, R Decorte, O Lao, M Kayser, T Kraaijenbrink, and P de Knijff (2020). The Dutch Y-chromosomal landscape. European journal of human genetics, 28, 287-299.

Altschul, M (1965). A Baronial Family in Medieval England: The Clares, 1217-1314. Baltimore, Johns Hopkins University Press.

Ball, FE (1927). Judges in Ireland, 1221-1921. New York, E.P. Dutton and Company.

Best, RI and E MacNeill (1933). The annals of Inisfallen: Reproduced in facsimile from the original manuscript (Rawlinson B503) in the Bodleian Library. Dublin, Royal Irish Academy.

Blomefield, F, C Parkin and W Miller (1805). An essay towards a topographical history of the county of Norfolk Volume 1. London, printed for William Miller.

Brand, P and J Getzler (2012). Judges and judging in the history of the Common Law and Civil Law: From antiquity to modern times. Cambridge, Cambridge University Press.

Brennan, TA (1979). A history of the Brennans of Idough, County Kilkenny. Lebanon, New Hampshire, Whitman Press Inc.

Britannica, Editors of Encyclopaedia (2015). Norman. Encyclopaedia Britannica.

Brooks, ESJ (1950). Knights' fees in counties Wexford, Carlow and Kilkenny, 13th-15th-century: With commentary. Dublin, Stationery Office.

Brown W (1914). Yorkshire Deeds, Record Series Volume 39. Leeds, Knight and Forster.

Brown, P (1987). Sibton Abbey cartularies and charters: Part 3. Woodbridge, Boydell for the Suffolk Records Society.

Brown RA (1951). Framlington castle and Bigod. Proceedings of the Suffolk Institute of Archaeology and Natural History 25, 127-148.

Brown K and S Ogilvie (2009). Concise encyclopaedia of languages of the world. Amsterdam, Elsevier.

Brunel S, et al. (2000). Ancient genomes from present-day France unveil 7,000 years of its demographic history. Proceedings of the National Academy of Sciences, 117, 12791-12798.

Busby, GB et al. (2001). The peopling of Europe and the cautionary tale of $Y$ chromosome lineage RM269. Proceedings of the Royal Society B: Biological Sciences, 279, 884-892.

Butler, R (1849). The annals of Ireland by Friar John Clyn. Dublin, Irish Archaeological Society.

Carrigan, W (1905). The History and Antiquities of the Diocese of Ossory. Dublin, Sealy, Bryers and Walker.

Cassidy, L, (2016). A Genomic Compendium of an Island: Documenting Continuity and Change across Irish Human Prehistory, Trinity College Dublin School of Genetics \& Microbiology.

(C) Copyright 2021 | All rights reserved | The Fitzpatrick Clan Society

Fitzpatrick, M., Fitzpatrick, I. (2021). The Similar-Sounding Surnames of Haplogroup R-BY140757. The Journal of the Fitzpatrick Clan Society 2, 1-41. doi:10.48151/fitzpatrickclansociety00421, 25 June 2021 
Cassidy, LM, R Martiniano, EM Murphy, MD Teasdale, J Mallory, B Hartwell, and DG Bradley, (2016). Neolithic and Bronze Age migration to Ireland and establishment of the insular Atlantic genome. Proceedings of the National Academy of Sciences of the United States of America, 113, 368-373.

City of Westminster Archives Centre (2021). Westminster Church of England Parish Registers; Reference: SMNA/PR/2/1.

Clay, CT (1924). Yorkshire Deeds, Volume 4. Leeds, John Whitehead \& Son Ltd.

Clay, CT (1930). Yorkshire Deeds, Volume 6. Leeds, John Whitehead \& Son Ltd.

Comerford, P (2005). The last pre-reformation Bishop of Ferns and his 'nephew', the Dean of Ossory, Journal of the Wexford Historical Society, 20, 156-172.

Copinger, WA (1910). The manors of Suffolk: notes on their history and devolution Volume 6. Manchester, Taylor, Garnet, Evans, and Co. Ltd.

Cunningham, B (2004). The world of Geoffrey Keating: History, myth and religion in seventeenthcentury Ireland. Dublin: Four Courts Press.

Curtis, E (Ed.) (1932). Calendar of Ormond deeds Volume I. Dublin, The Stationery Office.

Curtis, E (Ed.) (1934). Calendar of Ormond deeds Volume II. Dublin, The Stationery Office.

Curtis, E and RB McDowell (1968). Irish historical documents 1172-1922. London, Methuen and Co. Ltd.

Dawes, MBD, AC Wood and DH Gifford (1970). Calendar of Inquisitions Post Mortem: Volume 15, Richard II. London. Her Majesty's Stationery Office.

Davenport, JS (2007). The James River Davenport Search, including Lancelot, Prince George, and Williamsburg: Davenport appearances in various records. http://homepages.rootsweb.com/ nvjack/davnport/jamesriverdavenports.pdf

Davidson, V (1930). History of Wilkinson County. Macon, GA, Press of the J.W. Burke Company.

Devenish RJ and C McLaughlin (1948). Historical and genealogical records of the Devenish families of England and Ireland with an inquiry into the origin of the family name and some account of the family lines founded by them in other countries. Chicago, Lakeside Press.

Dodwell, B. (1952). Feet of fines for the county of Norfolk for the tenth year of the reign of King Richard the first, 1198-1199 and for the first four years of the reign of King John, 1199-1202. London, the Pipe Roll Society.

Drummond, AJ, OG Pybus, A Rambaut, R Forsberg, AG Rodrigo (2013). Measurably evolving populations. Trends in Ecology and Evolution,18, 481-488.

Empey, C (1971). The Cantreds of the Medieval County of Kilkenny. The Journal of the Royal Society of Irish Antiquaries of Ireland, 101, 128-134.

(C) Copyright 2021 | All rights reserved | The Fitzpatrick Clan Society

Fitzpatrick, M., Fitzpatrick, I. (2021). The Similar-Sounding Surnames of Haplogroup R-BY140757. The Journal of the Fitzpatrick Clan Society 2, 1-41. doi:10.48151/fitzpatrickclansociety00421, 25 June 2021 
England Births and Christenings (2021). 1538-1975 Database. FamilySearch. http://FamilySearch.org: 12 April 2021. Index based upon data collected by the Genealogical Society of Utah, Salt Lake City. Farrer, W (1914). Early Yorkshire charters, Volume 1. Edinburgh, Ballantyne, Hanson \& Co.

Farrer, W (1915). The Sheriffs of Lincolnshire and Yorkshire, 1066-1130. The English Historical Review, 30, 277-285.

Farrer, W and Clay, CT (1955). Early Yorkshire charters, Volume 10. New York, Cambridge University Press.

Fisher, EJ (1954). Some Yorkshire estates of the Percies 1450-1650, [thesis], The University of Leeds, Leeds. Department of History, pp 185.

Fitzpatrick, AP (2018). Migration. In The Oxford Handbook of the European Iron Age, Edited by Colin Haselgrove, Katharina Rebay-Salisbury, and Peter S. Wells. Oxford, Oxford University Press.

Fitzpatrick, M (2020a). Mac Giolla Phádraig Osraí 1384-1534 AD Part I. The Journal of the Fitzpatrick Clan Society 1, 1-17. doi:10.48151/fitzpatrickclansociety00120

Fitzpatrick, M (2020b). Mac Giolla Phádraig Osraí 1384-1534 AD Part II. The Journal of the Fitzpatrick Clan Society 1, 40-71. doi:10.48151/fitzpatrickclansociety00320

Fitzpatrick E and M Fitzpatrick (2020a). When everything changes: using critical family history to deconstruct Keesing and Fitzpatrick surnames, Genealogy, 4, 25. doi.org/10.3390/genealogy4010025

Fitzpatrick I and M Fitzpatrick (2020b). Colonial American Fitzpatrick Settlers, Part I: Making Sense of One Line. The Journal of the Fitzpatrick Clan Society 1, 18-39. doi:10.48151/fitzpatrickclansociety00220

Frame, R (1972). The Justiciar and the Murder of the MacMurroughs in 1282. Irish Historical Studies, $18,223-230$.

Frame, R. (1998). Ireland and Britain, 1170-1450. London: Hambledon.

Galenson, DW (1978). British Servants and the Colonial Indenture System in the Eighteenth Century. The Journal of Southern History, 44, 41-66.

Gardner RV (2003). Moated site at Branham Hall, Brantham. SCCAS Report No. 2003/39. Suffolk County Council Archaeological Service.

Graves J (1850). The Ancient Tribes and Territories of Ossory. No. I. Transactions of the Kilkenny Archaeological Society, 1, 230- 247.

Hartland, B (2003). To Serve Well and Faithfully: The Agents of Aristocratic English Lordship in Leinster ca. 1272-ca. 1315. Medieval Prosopography, 24, 195-245.

Harper-Bill, C. (1998). Dodnash Priory charters. Suffolk, Boydell Press for the Suffolk Records Society.

Healy, W (1893). History and antiquities of Kilkenny (County and City): With illustrations and appendix, compiled from inquisitions, deeds, wills, funeral entries, family records, and other historical and authentic sources. Vol. 1. Kilkenny, Egan.

(C) Copyright 2021 | All rights reserved | The Fitzpatrick Clan Society

Fitzpatrick, M., Fitzpatrick, I. (2021). The Similar-Sounding Surnames of Haplogroup R-BY140757. The Journal of the Fitzpatrick Clan Society 2, 1-41. doi:10.48151/fitzpatrickclansociety00421, 25 June 2021 
Henning, BD (1983). The History of Parliament: the House of Commons 1660-1690.

Hogan, J (1864). Topographical and Historical Illustrations of the County of Kilkenny (Continued). The Journal of the Kilkenny and South-East of Ireland Archaeological Society, 1864, 5, 189-214.

Illingworth, W (1818). Placita de quo warranto temporibus Edw. I. II. and III. in curia receptae scaccarij Westm. Asservata. London, : G. Eyre and A. Strahan.

Ireland (1904). Thirty-sixth report of the Deputy Keeper of the Public Records and Keeper of the State Papers in Ireland. Dublin, Alexander Thom for His Majesty's Stationary Office.

Irish Record Commission. (1800). Calendar [of patent rolls of Ireland: 1-22 James I]. Dublin: Irish Record Commission.

Jolliffe, W (1893). Historical, Genealogical, and Biographical Account of the Jolliffe Family of Virginia: 1652 to 1893: also sketches of the Neill's, Janney's, Hollingsworth's, and other cognate families. Philadelphia, J. B. Lippincott Co.

Karakachoff M, et al.(2015). Fine-scale human genetic structure in Western France. European Journal of Human Genetics, 23, 831-836.

Keating, G (1723). The general history of Ireland: Containing. London printed by J Bettenham, for B Creake, Jermyn Street, St. James's.

Kelly, MT (1895). A bishop-king of Cashel. Journal of the Cork Historical and Archaeological Society, 1, 193-200.

Keim, CR (1968). Primogeniture and Entail in Colonial Virginia. The William and Mary Quarterly, 25, 545-586.

King, GHS, 1966 The Registers of North Farnham Parish 1663-1814 and Lunenburg Parish 1783-1800, Richmond County, VA, compiled by George Harrison Sanford King

Koch, JT and A Holley (2006). Celtic culture: A historical encyclopedia. Santa Barbara, ABC-Clio.

Lancaster, RA (1936). Wales, Dinwiddie County, Virginia. The Virginia Magazine of History and Biography, 44, 232-237.

Lodge, J (1789). The peerage of Ireland: Or, a genealogical history of the present nobility of that kingdom. ... By John Lodge, Esq. Revised, enlarged and continued to the present time; by Mervyn Archdall. London, Printed for G.G.J. and J. Robinson.

Lucotte, G (2015). The Major Y-Chromosome Haplogroup R1b-M269 in West-Europe, Subdivided by the Three SNPs S21/U106, S145/L21 and S28/U152, Shows a Clear Pattern of Geographic Differentiation. Advances in Anthropology, 5, 22-30.

MacCarthy, B (1895). Annals of Ulster, otherwise, Annala senait, Annals of senat: : a chronicle of Irish affairs from A.D. 431 to A.D. 1540. Dublin, Her Majesty's Stationery Office.

Mac Fhirbhisigh, D and Ó Muraíle, N. (2003).Leabhar Mór na nGenealach. Dublin, De Burca. 
MacLysaght, E (1985). Irish Families: Their Names, Arms and Origins. Dublin, Irish Academic Press.

MacNeill, E (1920). Phases of Irish History. Dublin, MH Gill and Son Ltd.

MacNeill, E (1921). Celtic Ireland. Dublin: Martin Lester.

Martínez-Cruz, B, C Harmant, DE Platt, W Haak, J Manry, E Ramos-Luis, DF Soria-Hernanz, F Bauduer, J Salaberria, B Oyharçabal, L Quintana-Murci, D Comas, and the Genographic Consortium (2012). Evidence of Pre-Roman Tribal Genetic Structure in Basques from Uniparentally Inherited Markers, Molecular Biology and Evolution, 29, 2211-2222.

Maxwell Lyte HC (1894). A Descriptive Catalogue of Ancient Deeds: Volume 2. London, Eyre and Spottiswoode.

Mclnerney, L (2017). A most vainglorious man. Archivium Hibernicum, 70, 202-283.

Mills, J (1905). Calendar of the justiciary rolls: Or, Proceedings in the Court of the justiciar of Ireland preserved in the Public record office of Ireland. Dublin, His Majesty's Stationery Office.

Mills, J (1914). Calendar of the justiciary rolls preserved in the Public record office of Ireland. Dublin, Printed for His Majesty's Stationery Office by A. Thom \& Co. Limited.

Moore, LT, B McEvoy, E Cape, K Simms, and DG Bradley (2006). A Y-chromosome signature of hegemony in Gaelic Ireland. American journal of human genetics, 78, 334-338.

Morris, H (1922). The Ancient Kingdom of Ossory. II. The Irish Monthly, 50, 279-282.

Morris, M (2015). The Bigod Earls of Norfolk in the thirteenth century. Woodbridge, Suffolk, Boydell Press.

Murphy, N (1879). The O'Brenans and the ancient territory of Hy-Duach. Transactions of the Ossory Archaeological Society, 1, 393-407.

Ní Mhaonaigh, M (1996). Cogad Gáedel Re Gallaib and the Annals: A Comparison. Ériu, 47, 101-126.

Nugent, NM (1979). Cavaliers and pioneers: Abstracts of Virginia land patents and grants. Volume Three: 1695-1732. Richmond, VA: Virginia State Library and Archives.

O'Brien MA (1976). Corpus Genealogiarum Hiberniae. Dublin, Dublin Institute for Advanced Studies.

Ó Canann, T (2002). The Journal of the Royal Society of Antiquaries of Ireland, 132, 127-137.

O'Clery, M., O'Clery, C., O'Clery, C., O'Mulconry, F., O'Duigenan, C., \& O'Donovan, J. (1856). Annals of the Kingdom of Ireland, by the Four Masters, from the earliest period to the year 1616. Dublin, Hodges, Smith, and Co.

Ó Corráin, D (1977). The education of Diarmait Mac Murchada. Ériu, 28, 71-81.

O'Curry, E (1861). Lectures on the Manuscript Materials of Ancient Irish History. Dublin, James Duffy.

(C) Copyright 2021 | All rights reserved | The Fitzpatrick Clan Society

Fitzpatrick, M., Fitzpatrick, I. (2021). The Similar-Sounding Surnames of Haplogroup R-BY140757. The Journal of the Fitzpatrick Clan Society 2, 1-41. doi:10.48151/fitzpatrickclansociety00421, 25 June 2021 
Ó Donnchada T (1940). An Leabhar Muimhneach: Maraon le suim aguisíní. Dublin, Oifig díolta foillseacháin rialtais.

O'Donovan, J. (1860). Annals of Ireland. Three Fragments, copied from ancient sources by Dubhaltach Mac Fhirbhisigh. Dublin. University Press.

O'Dubhagain, S, J O'Donovan, and G O'Huidhrin (1862).The topographical poems of John O'Dubhagain and Giolla Na Naomh O'Huidhrin. Dublin: Printed for the Irish Archaeological and Celtic Society by Alexander Thom.

O'Hart, J (1892). Irish Pedigrees. Dublin, James Duffy and Co. Ltd.

Ó Murchadha, D (1999). The Formation of Gaelic Surnames in Ireland: Choosing the Eponyms. Nomina 22, 25-44.

O'Sullivan, A (1983). The book of Leinster. Dublin, Dublin Inst. for Advanced Studies.

Otway-Ruthven, AJ. (1961). Liber Primus Kilkenniensis. Kilkenny: E. Smithwick and Sons.

Otway-Ruthven, AJ (1980). A history of medieval Ireland. London, E. Benn.

Palgrave, F (1835). Rotuli Curiae Regis Volume 1. Great Britain, The Commissioners of the Public Records of the Kingdom.

Paul, JB (1904). The Scots peerage: Founded on Wood's edition of Sir Robert Douglas's Peerage of Scotland ; containing an historical and genealogical account of the nobility of that kingdom.

Edinburgh, D. Douglas.

Pender, S (1951). The O Clery Book of Genealogies: 23 D 17 (RIA). Analecta Hibernica, 18, 1-198.

Pipe Roll Society (1890). The great roll of the pipe for the fourteenth year of the reign of king Henry the Second, A.D. 1167-1168. London, Hansard Publishing Union.

Pope, R (2021). Re-approaching Celts: origins, society, and social change. Journal of Archaeological Research: https://doi.org/10.1007/s10814-021-09157-1

Prim, JGA (1864). Memorials of the Family of Langton of Kilkenny. The Journal of the Kilkenny and South-East of Ireland Archaeological Society, 1864, 5, 59-84.

Richardson, HG and GO Sayles (1947).Parliaments and councils of mediaeval Ireland. Dublin: Stationery Office.

Robinson, WS (1957). Mother earth - land grants in Virginia, 1607-1699. [With plates, including a portrait and a facsimile, and with a bibliography]. Williamsburg.

Roskell, JS, L Clark, and C Rawcliffe (1993). The History of Parliament: The House of Commons 13861421. Stroud, England, Alan Sutton.

Royal Society of Antiquaries of Ireland, 1879. The Journal of the Royal Historical and Archaeological Association of Ireland, 5, 3-15.

(C) Copyright 2021 | All rights reserved | The Fitzpatrick Clan Society

Fitzpatrick, M., Fitzpatrick, I. (2021). The Similar-Sounding Surnames of Haplogroup R-BY140757. The Journal of the Fitzpatrick Clan Society 2, 1-41. doi:10.48151/fitzpatrickclansociety00421, 25 June 2021 
Rye, W (1900). A Calendar of the feet of fines for Suffolk. Ipswich, The Ancient House.

Scholar, $H$ (2020). The ghost of the ' $Y$ ': Paternal DNA, haunting and genealogy. Genealogy, 4, 3.

Sharp, JEES (1904). Calendar of Inquisitions Post Mortem: Volume 1, Henry III. London. His Majesty's Stationery Office.

Sharp, JEES (1906). Calendar of Inquisitions Post Mortem: Volume 2, Edward I. London. His Majesty's Stationery Office.

Sharp, R (2014). Charters of William II and Henry I Project: https://actswilliam2henry1.files.wordpress.com/2013/04/h1-adam-the-clerk-2014-1.pdf

Sharp, JEES and AE Stamp (1908). Calendar of Inquisitions Post Mortem: Volume 5, Edward II. London. His Majesty's Stationery Office.

Sharp, JEES and AE Stamp (1913). Calendar of Inquisitions Post Mortem: Volume 4, Edward I. London. His Majesty's Stationery Office.

Stamp, AE, JBW Chapman, MCB Dawes and DB Wardle (1954). Calendar of Inquisitions Post Mortem: Volume 13, Edward III. London. Her Majesty's Stationery Office.

Stamp, AE, E Salisbury, EG Atkinson and JJ O'Reilly (1921). Calendar of Inquisitions Post Mortem: Volume 10, Edward III. London. His Majesty's Stationery Office.

Story-Maskelyne AS and HC Maxwell Lyte, 1898. Calendar of Inquisitions Post Mortem: Series 2 , Volume 1, Henry VII. London. Her Majesty's Stationery Office.

Story-Maskelyne AS and HC Maxwell Lyte (1915). Calendar of Inquisitions Post Mortem: Series 2, Volume 2, Henry VII. London. His Majesty's Stationery Office.

Shearman, J (1878). Loca Patriciana: An Identification of Localities, Chiefly in Leinster, Visited by Saint Patrick and His Assistant Missionaries and of Some Contemporary Kings and Chieftains. Dublin, M. H. Gill.

Simms, K (2004). The Macmahon genealogy: a medieval forgery. In Regions and rulers in Ireland, 1100-1650. Edited by David Edwards. Dublin, Four courts Press.

Sparacio R and S Sparacio (1989). Deed and will book, Old Rappahannock County, Virginia 16651677. Springfield, VA, Antient Press.

Sparacio, R and S Sparacio (1991). Deed abstracts of Richmond County, Virginia, 1692-1695. McLean, VA, Antient Press.

Speight, H (1894). Nidderdale and the garden of Nidd: a Yorkshire Rhineland. London, Elliot Stock.

Stanley Price, MJ (1955). Yorkshire Deeds, Volume 10. Leeds, John Whitehead \& Son Ltd.

Stenton, D (1952). Pleas Before the King Or His Justices, 1198-1202: Rolls or fragments of rolls from the years 1198, 1201 and 1202. London, Quaritch.

Sweetman, H S (1875). Calendar of documents relating to Ireland preserved in Her Majesty's Public Record Office, London, 1171-1251. London, Longman \& Co.

(C) Copyright 2021 | All rights reserved | The Fitzpatrick Clan Society

Fitzpatrick, M., Fitzpatrick, I. (2021). The Similar-Sounding Surnames of Haplogroup R-BY140757. The Journal of the Fitzpatrick Clan Society 2, 1-41. doi:10.48151/fitzpatrickclansociety00421, 25 June 2021 
Sweetman, HS (1877). Calendar of documents relating to Ireland preserved in Her Majesty's Public Record Office, London, 1252-1284. London, Longman \& Co.

Sweetman, HS (1879). Calendar of documents relating to Ireland preserved in Her Majesty's Public Record Office, London, 1285-1292. London, Longman \& Co.

Sweetman, HS (1881). Calendar of documents relating to Ireland preserved in Her Majesty's Public Record Office, London, 1293-1301. London, Longman \& Co.

Sweetman, HS (1886). Calendar of documents relating to Ireland preserved in Her Majesty's Public Record Office, London, 1302-1307. London, Longman \& Co.

Talmadge, JY, WF Dykes and Daughters of the American Revolution (1926). Historical collections of the Georgia chapters, Daughters of the American Revolution. Atlanta, CP Byrd, State printer.

Tanner, T. (1787). Notitia Monastica. Cambridge, Printed at the University Press, by John Archdeacon for John Nichols.

The Medieval Soldier (2021). Information on soldiers has been taken from the AHRC-funded The Soldier in Later Medieval England Online Database, www.medievalsoldier.org, 20 May 2021.

The William and Mary Quarterly (1915). Records of Dinwiddie County, 23, 214-218.

Todd, JH (1867). Cogadh Gaedhel ke Gallaibh: The war of the Gaedhil with the Gaill, or the invasions of Ireland by the Danes and other Norsemen. London, Longmans, Green, Reader \& Dyer.

Tresham, E (1828). Rotulorum patentium et clausorum Cancellariæ hiberniæ calendarium: Vol. I. Pars. I. Dublin: His Majesty's printers.

Walsh, P (1933). Gleanings from Irish manuscripts. Dublin, At the sign of the three candles.

Walsh, P (1942). An Leabhar Muimhneach. Irish Historical Studies, 3, 135-143.

Ward, JC (1962). The estates of the Clare family, 1066-1317 [thesis], Queen Mary. University of London, pp 367.

West Yorkshire Archive Service (2021). Yorkshire Parish Records; New Reference Number: RDP96/1.

White, NB (1932). The Red Book of Ormond, A. D. 1200-1600. Dublin, Irish Manuscripts Commission.

White, NB (1936). Irish monastic and episcopal deeds, A. D. 1200-1600. Dublin, Irish Manuscripts Commission.

White, R (1895). The registers of Monk Fryston, in the West Riding of Yorkshire. Worksop, Printed by R. White.

Wood, H, AE Langman and MC Griffith (1905). Calendar of the justiciary rolls, or proceedings in the Court of the Justiciar of Ireland. Dublin: Stationery Office.

Zalewski, S and R Fitzpatrick (2002). Descendants of Bryan Fitzpatrick Lord and First Baron of Upper Ossory. Dublin, Zalewski \& Fitzpatrick. 


\section{Appendix 1: Descendant-haplotree of Richard Branham}

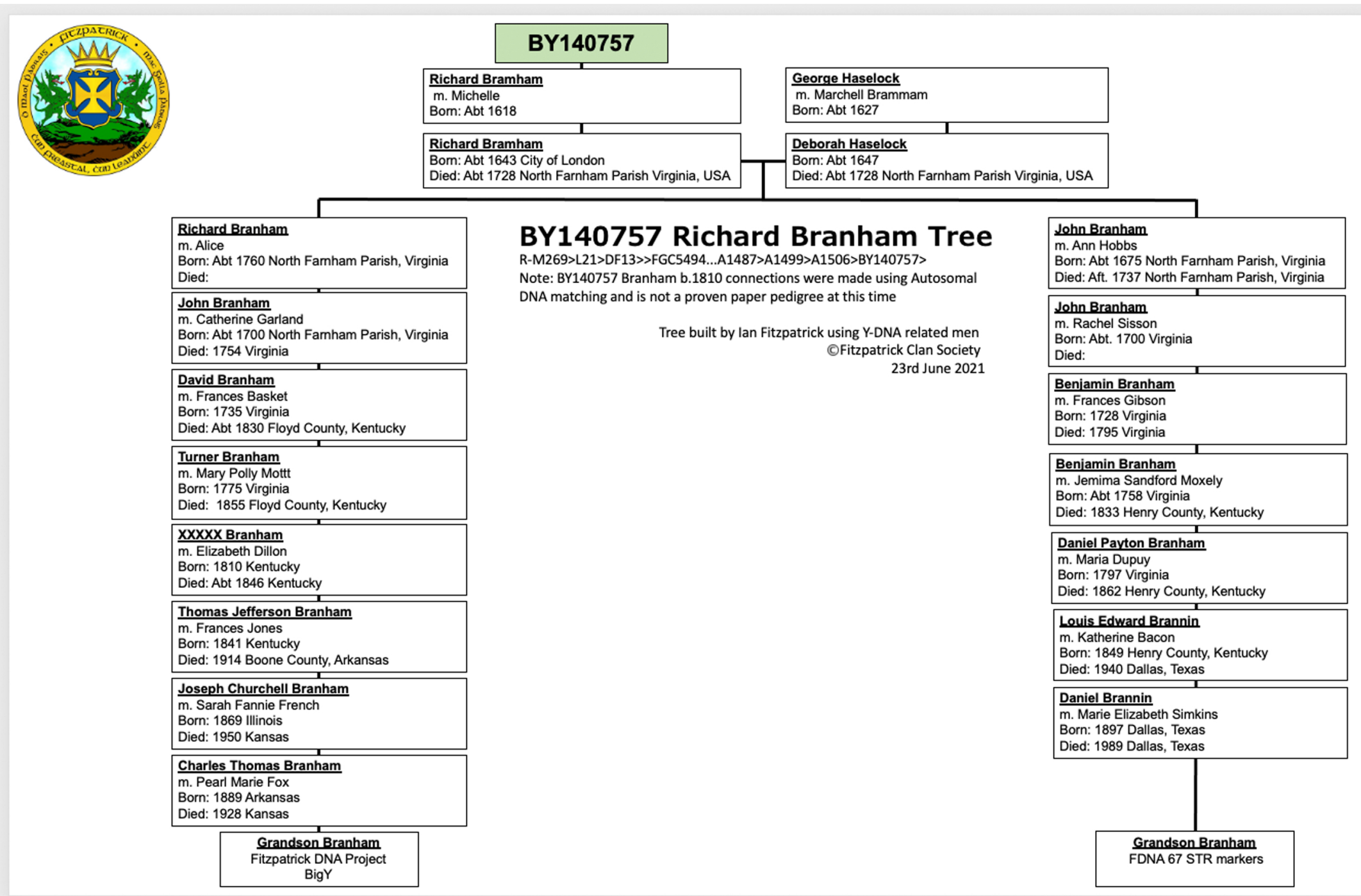




\section{Appendix 2: Descendant-haplotree of Caran Branan}

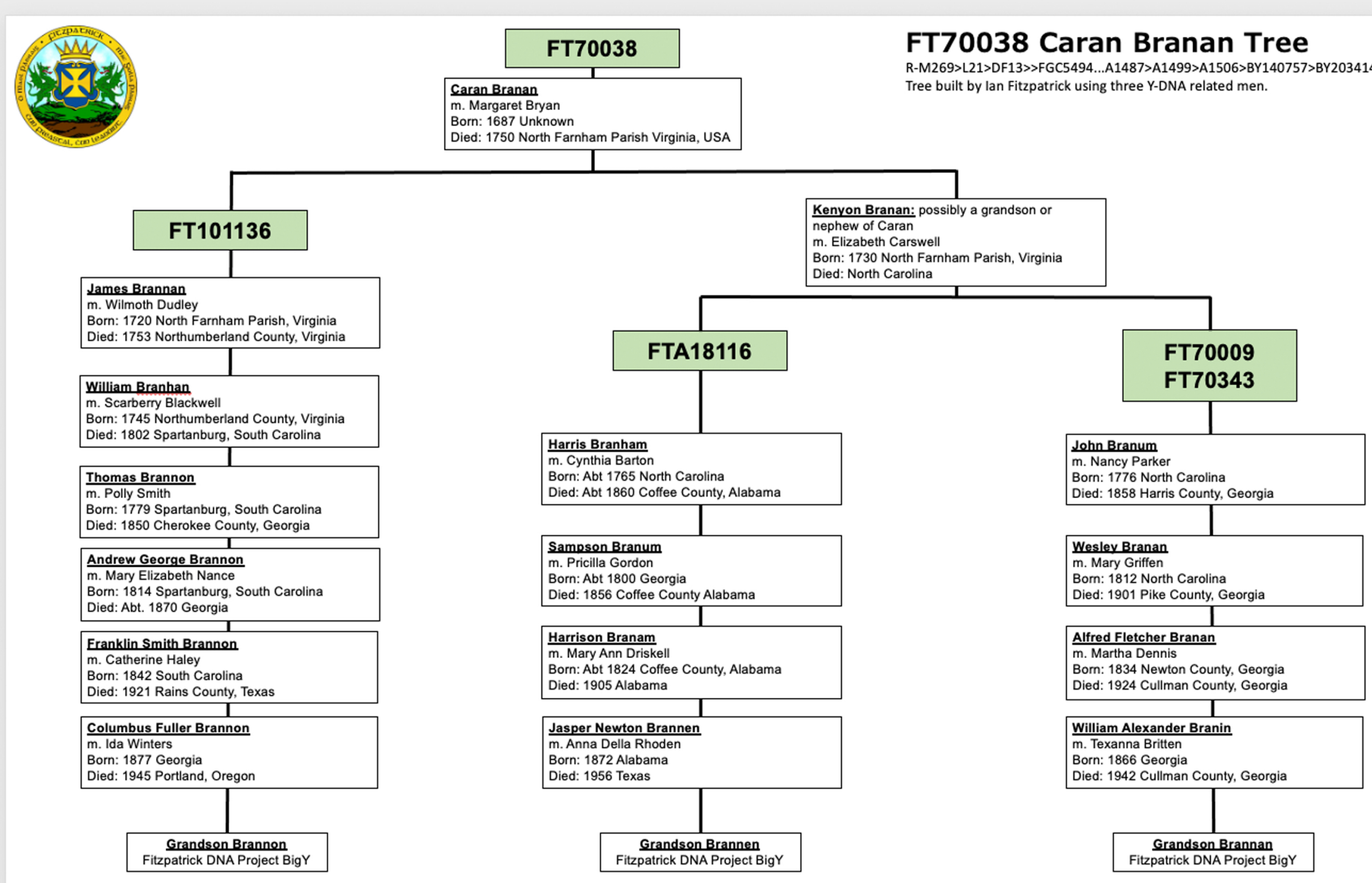




\section{Appendix 3: R-BY140757 Haplotree}

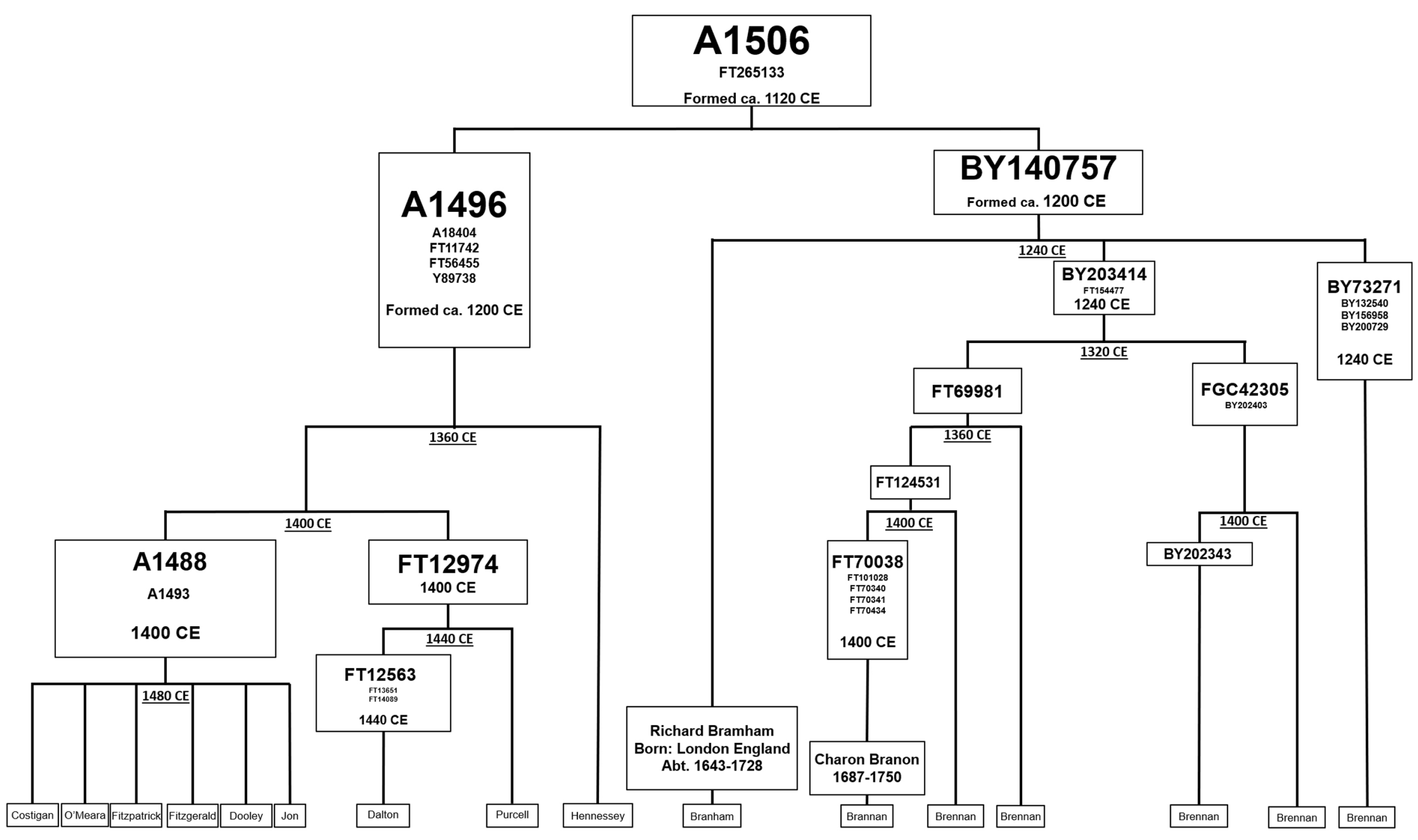

